\title{
UČINAK COVID-A 19 NA PREKOGRANIČNE UGOVORE VEZANE UZ ORGANIZACIJU SPORTSKIH NATJECANJA
}

\author{
UDK: 616.2-036.21: 796.093 \\ DOI: $10.31141 /$ zrpfs.2021.58.139.121 \\ Izvorni znanstveni rad \\ Primljeno: 25. listopada 2020.
}

U okolnostima u kojima se prekogranična mobilnost stvari i osoba uzimala zdravo za gotovo, pandemijski razmjeri epidemije virusa SARS-CoV-2 (kolokvijalno zvan koronavirus, dok je nova bolest dobila naziv COVID-19) rezultirali su dramatičnim i do jučer nezamislivim posljedicama. Naime, u redovnom tijeku stvari uglavnom smo se fokusirali na njezine pozitivne efekte, no aktualna epidemija do kraja je razotkrila i njezino „drugo lice“. COVID-19 pokazao se najboljim „stres testom“ prekogranične mobilnosti osoba i prekograničnih gospodarskih odnosa i ukazao na sve slabosti pretjeranog oslanjanja na globalizaciju per se. Učinak COVID-a 19 na svaki aspekt života i na čovječanstvo u cjelini može se nazvati kolosalnim. Pod naletom epidemije „stradali“ su brojni sektori, uključujući i sportski. Većina je sportskih natjecanja, osobito regionalnih i globalnih, otkazana ili odgođena na (ne)određeno vrijeme. Federacije i organizatori sportskih natjecanja našli su se u velikim problemima uslijed nemogućnosti ispunjenja svojih ugovornih obveza u odnosu na sponzore, medije i druge ugovorne stranke. Namjera je autorice ovog rada pokušati odgovoriti na pitanje koje ovih dana muči mnoge, a to je mogućnost isključenja ili ograničenja ugovorne odgovornosti pozivanjem na višu silu.

Ključne riječi: prekogranična mobilnost, organizacija sportskih natjecanja, prekogranični ugovori, force majeure, Europska unija, globalna perspektiva

\section{UVOD}

Ljudski je rod od svojih početaka izložen različitim izazovima. Neki su posljedica različitih eksternalija, a nekima je uzrok sam čovjek. U ovom trenutku teško je tvrditi koji je uzrok izazovu s kojim nas je suočila 2020. godina. Je li riječ o događaju koji je prouzročio sam čovjek ili je riječ o prirodnom fenomenu vjerojatno ćemo znati tek post festum. ${ }^{2}$ U svakom slučaju, s početkom 2020. godine čovječanstvo

1 Izv. prof. dr. sc. Ines Medić, e-mail: ines.medic@pravst.hr

2 U svakom slučaju, teorija ne nedostaje, kako ozbiljnih tako i onih ,popularnih“. Tako tisak navodi da neki teolozi tvrde da se radi o početku fundamentalne promjene u društvu na koju ukazuje broj 40 (sadržan u broju 2020) koji je u korijenu svake bitne promjene navedene u Bibliji; pa navode da je 40 dana trajao potop, isto toliko Isusov post, a toliko traje i korizma. Sa 40 je godina Mojsije pobjegao iz Egipta i 40 dana ostao na Sinajskoj gori. Egzodus je trajao 40 godina. Broj četrdeset sadržan je i u latinskom korijenu riječi karantena. Vidi: http://www.hkz-kkv.ch/karantena.php, preuzeto 22. IV. 2020. Ima i onih koji tvrde da se radi o nekakvoj zavjeri itd. 
se suočilo s epidemijom virusa SARS-CoV-2 (kolokvijalno nazvanim koronavirus, a nova bolest COVID-19) koji je ubrzo poprimio pandemijske razmjere ${ }^{3}$ doveo do značajnih restrikcija nacionalne i prekogranične mobilnosti, a time i ozbiljnih problema u gospodarstvu: smanjene ili potpuno obustavljene proizvodnje, smanjenja ili obustavljanja nacionalnog i prekograničnog prijevoza, odgode ili otkazivanja turističkih aranžmana, odgode ili otkazivanja unaprijed dogovorenih projekata, kašnjenja ili neisporuke robe itd. ${ }^{4}$

Da je riječ o epidemiji ${ }^{5}$ pandemijskih ${ }^{6}$ razmjera Svjetska zdravstvena organizacija potvrdila je još u ožujku ove godine, ${ }^{7}$ nakon čega su i brojne nacionalne vlade proglasile stanje epidemije ${ }^{8}$ Uslijedila su različita ograničenja na nacionalnom i prekograničnom planu, odgođena su gotovo sva značajnija javna događanja, pa tako i sportska natjecanja. ${ }^{9}$

O razmjerima financijske štete moguće je zasada samo nagađati. U svakom slučaju, nakon inicijalnog refleksa usmjerenog ka očuvanju vrste i građanskoj solidarnosti, fokus se sve brže premješta na pravne i ekonomske implikacije epidemije. Već sad je očito da će posljedice epidemije biti znatne, da će se broj građanskopravnih sporova povećati te da je potrebno „raspetljati“ pitanje odgovornosti. Uz iznimku onih tržišnih aktera koji su se osigurali policama osiguranja u slučaju epidemije ili pandemije, većina će svoje gubitke nastojati nadoknaditi traženjem financijske pomoći od države ili putem suda. Sve se češće spominje „viša sila“ te drugi mehanizmi isključenja ili ograničenja odgovornosti.

3 Svjetska je zdravstvena organizacija (WHO) 11. ožujka 2020. godine proglasila globalnu pandemiju koronavirusa. Pandemija se definira kao globalno širenje nove bolesti koje je teško držati pod kontrolom. S posljednjom prijavljenom globalnom pandemijom svijet se suočio 2009. godine, a odnosila se na širenje virusa gripe H1N1 i smrt stotina tisuća ljudi na svijetu. Međutim, prvi zapisi pandemije na svijetu sežu u daleku 1580. godinu. Nakon toga, zabilježene su još četiri pandemije u 19. stoljeću i tri u 20. Najtežom se smatra pandemija španjolske gripe iz 1918. godine koja je zarazila gotovo trećinu svjetske populacije te usmrtila oko 50 milijuna ljudi širom svijeta. Detaljnije vidi: Krmpotić, Ž.: https://www.24sata.hr/lifestyle/ sto-se-zapravo-krije-iza-pojma-pandemija-i-kad-se-proglasava-678096, preuzeto 1. III. 2020.

4 Više vidi u: Cesarec Nöthig, S., Štaba, R.: Epidemija virusom SARS-CoV-2 (COVID-19; „KORONAVIRUS“) - viša sila kao razlog isključenja ili ograničenja odgovornosti, https://www.psod.hr/ objave/epidemija-virusom-covid-19-koronavirus---visa-sila , preuzeto 16. III. 2020.

5 Od grčke riječi „epi“ - nad i „demos“ - ljudi. Označava naglo obolijevanje većeg broja ljudi na određenom području u kratkom razdoblju. Hrvatska enciklopedija, mrežno izdanje. Leksikografski zavod Miroslav Krleža, 2020., http://www.enciklopedija.hr/Natuknica.aspx?ID=46397, preuzeto 26. IV. 2020.

6 Od grčke riječi ,pan“ - svi i ,demos“" - ljudi. Označava širenje neke bolesti na velika prostranstva, tj. na više država, cijeli kontinent ili cijeli svijet. Hrvatska enciklopedija, mrežno izdanje. Leksikografski zavod Miroslav Krleža, 2020., http://www.enciklopedija.hr/Natuknica.aspx?ID=18092 , preuzeto 26. IV. 2020.

7 Vidi bilj. 3.

8 Vlada RH proglasila je epidemiju 12. ožujka 2020.

9 Tako je otkazana sezona NBA-e, preostalo zimsko i proljetno prvenstvo NCAA-e itd. Među odgođenima su golf Masters, Bostonski maraton, Londonski maraton, Olimpijske igre u Tokiju, Invictus Games itd. Više vidi u: ESPN: Coronavirus cancellations and reactions in sports, https://www.espn.com/ espn/story/_/id/28871525/coronavirus-cancellations-reactions-sports, preuzeto 24. IV. 2020. 


\section{SPECIFIČNOSTI SPORTSKOG SEKTORA}

Iako sport nije, niti bi trebao biti u prvom planu, nemoguće je ne primijetiti da je COVID-19 izazvao neviđene poremećaje i u tom sektoru, kako horizontalne tako i vertikalne. To je ugrozilo ne samo natjecanja, nego i radna mjesta u pravnim osobama u sustavu sporta, a također i ispunjenje ugovornih obveza vezanih uz organizaciju sportskih natjecanja. Neki su situaciju pokušali ublažiti prijedlogom da se određena natjecanja odvijaju bez publike ${ }^{10} \mathrm{i}$ tako spase barem prihodi od TVprijenosa, ${ }^{11}$ ali prijedlog zasad nije prihvaćen. Osobito kad je riječ o događajima koji su odgođeni za neki budući datum u kojemu zdravstvene mjere poduzete danas više ne moraju biti na snazi.

S obzirom na jačinu „potresa“ izazvanog COVID-om 19, neke su sportske federacije predstavile vlastite smjernice za reguliranje novonastale situacije. Primjerice, FIFA je 7. travnja 2020. godine predstavila smjernice za što sigurniji povratak nogometu, pod nazivom „COVID-19, regulatorna pitanja u nogometu“, vezane uz početak i istek igračkih ugovora, igračke ugovore koji se više ne mogu izvršavati, prijelazne rokove itd. ${ }^{12} \mathrm{~S}$ obzirom na to da je riječ o smjernicama čija provedba u praksi ovisi ponajprije o suglasnosti stranaka, prilično je očito na što će se odnositi budući sporovi. Primjerice, na sporove vezane uz ugovore o radu (igranju), sporove između nacionalnih Olimpijskih saveza i sportaša, sporove između međunarodnih saveza i članova saveza, sponzorske ugovore, ugovore o radiotelevizijskom emitiranj, itd. Vezano uz organizaciju sportskih natjecanja, tu su još i ugovori o pružanju različitih usluga, ugovori o prijevozu i slično.

Drugim riječima, broj i vrste ugovora sklopljenih u vezi s organizacijom sportskih natjecanja često je teško i pobrojiti. Stoga je nemoguće podvesti ih sve pod ,istu kapu“. Naime, pored toga što svaka vrsta ugovora ima svoje specifičnosti, za različite vrste ugovora mjerodavni su i različiti izvori prava. ${ }^{13}$ To je osobito potencirano kod ugovora s prekograničnim obilježjem kod kojih su „u igri“ i međunarodni izvori prava, kojih već sad ima pozamašan broj i o kojima je u slučaju spora itekako potrebno voditi računa.

Kada su u pitanju ugovori s natjecateljima i ugovori o gostovanju, pored lex sportiva bit će mjerodavno i neko nacionalno pravo, i to najčešće švicarsko, jer je za takve sporove u pravilu ugovorena nadležnost Arbitražnog suda za Sport (CAS) sa sjedištem u Lauseannei. ${ }^{14}$

10 Tako npr. Tour de France. https://www.bbc.com/sport/cycling/52050109, preuzeto, 5. IV. 2020.

11 Kako je većina sportskih događanja odgođena do daljnjega, televizijske su kuće suspendirale plaćanje prava TV-prijenosa. Primjerice Canal Plus i Beln Sports objavili su suspenziju plaćanja televizijskih prava na prijenos nogometnih utakmica francuske lige zbog odgode natjecanja. https://www. sportspromedia.com/news/bein-sports-lfp-ligue-1-tv-rights-instalments-suspended-coronavirus, preuzeto 5. IV. 2020.

12 Vidi: https://img.fifa.com/image/upload/zyqtt4bxgupp6pshcrtg.pdf, preuzeto 25. IV. 2020.

13 Vidi: Medić, I.: „Applicable Law for Contracts in Sporting Context“, Journal of South East European University (SEEU Review), Vol. 12, Issue 1; Medić, I.: „Međunarodno privatno pravo u sportu (kolizijske norme)“, u: Kačer, H. et. al.: Sportsko pravo, Split: Pravni fakultet, 2018., str. 447-473.

14 Court of Arbitration for Sport (CAS). 
Izv. prof. dr. sc. Ines Medić: Učinak COVID-a 19 na prekogranične ugovore vezane uz organizaciju... Zbornik radova Pravnog fakulteta u Splitu, god. 58, 1/2021, str. 121-150

U odnosu na ostale ugovore, u većini prekograničnih ugovora mjerodavno pravo za ugovor određuje se temeljem odredbi Uredbe Rim I. o pravu mjerodavnom za ugovorne obveze. ${ }^{15}$ Člankom 3. navedene Uredbe propisano je opće pravilo za B2B ugovore, prema kojemu stranke slobodno određuju mjerodavno pravo za svoj ugovor bez obveze da vode računa o koneksitetu, dakle bez obveze postojanja veze s odnosnim ugovorom. Pod uvjetom da klauzula o izboru mjerodavnog prava ispunjava uvjete materijalne i formalne valjanosti, ${ }^{16}$ nadležni sud primijenit će navedeno mjerodavno pravo vodeći računa o primjeni odredaba prava EU koje se ne mogu derogirati sporazumom stranaka, ${ }^{17}$ a također i o primjeni međunarodno prisilnih propisa prava države foruma. ${ }^{18}$

Nasuprot tome, neki su ugovori podvrgnuti Konvenciji UN-a o međunarodnoj prodaji robe ${ }^{19}$ pa je učinak više sile podložan tumačenju odredbe o višoj sili sadržane u toj Konvenciji. ${ }^{20} \mathrm{U}$ državama ugovornicama navedene konvencije, odredbe te

15 Uredba (EZ) br. 593/2008 Europskog parlamenta i Vijeća od 17. lipnja 2008. o pravu koje se primjenjuje na ugovorne obveze (Rim I), Sl. 1. L 177, od 4. VII. 2008. Jednako je tako i u hrvatskom međunarodnom privatnom pravu jer i Zakon o međunarodnom privatnom pravu RH iz 2017. godine u pogledu određivanja mjerodavnog prava za ugovore upućuje na Uredbu Rim I. Dakle, ne postoji autonomno nacionalno rješenje za određivanje mjerodavnog prava za prekogranične ugovore, već se ono određuje temeljem odredaba Uredbe Rim I.

16 Uvjeti propisani čl. 10., 11. i 13. Uredbe Rim I.

17 Medić, I.: „Lex Contractus and Overriding Mandatory Rules. What Can We Learn from the CJEU Case Law?", Book of Proceedings, 16th International Scientific Conference on Economic and Social Development - , ,The Legal Challenges of Modern World“, No. 16, Split, 2016., str. 43-52; Medić, I.: „Significance of Mandatory Rules in International Commercial Arbitration“, Book of Proceedings, 19th International Scientific Conference on Economic and Social Development, No. 19, Melbourne, 2019., str. 38-46; Sánchez Lorenzo, S.: „Choice of law and overriding mandatory rules in international contracts after Rome I“, Yearbook of Private International Law, Vol. 12, 2010., str. 61-79; Heiss, H.: „Party autonomy“. In Ferrari, F., Leible, S. (ur.), Rome I Regulation, The Law Applicable to Contractual Obligations, Munich: Sellier, European law publishers GmbH, str. 1-16.

18 Wojewoda, M.: „Mandatory Rules in Private International Law“, Maastricht J. Eur. \& Comp. L., Vol. 7, No. 2, 2000., str. 183-213; Kunda, I.: „Defining Internationally Mandatory Rules in European Private International Law of Contracts“, Zeitschrift für Gemeinschaftsprivatrecht (GPR), Vol. 4, No. 5, 2007., str. 210-220; Buxbaum, H. L.: Mandatory Rules in Civil Litigation: Status of the Doctrine PostGlobalization, Articles by Maurer Faculty, Paper 292, str. 22., http://www.repository.law.indiana.edu/ facpub/292, preuzeto 23. V. 2016.; Pauknerová, M.: „Mandatory rules and public policy in international contract law“, ERA Forum, 2010 (Vol. 11, No. 1), str. 29-43; Symeonides, S. C.: „Party Autonomy in Rome I and II From a Comparative Perspective“. In Boele-Woelki, K. et al. (ur.), Convergence and Divergence in Private International Law - Liber Amicorum Kurt Siehr, Zürich: Eleven International Publishing, str. 513-550; Schwartze, A.: „New Trends in Partie's Options to Select the Applicable Law? The Hague Principles on Choice of Law in International Cotracts in a Comparative Perspective“, University of St. Thomas Law Journal, Vol. 12, No 1, 2015., str. 87-99.

19 Prijevod teksta na hrvatski jezik dostupan je na: http://www.cisg.law.pace.edu/cisg/text/CISGCRO. html, preuzeto 12. I. 2020.

20 Više o tome vidi u: CISG Advisory Council Opinion no. 7, Exemption of Liability for Damages Under Article 79 of the CISG, http://www.cisg.law.pace.edu/cisg/CISG-AC-op/.html, preuzeto 6. IV. 2020. Liu, C.: Force Majeure. Perspectives from the CISG, UNIDROIT principles, PECL and Case Law (2nd edition: Case annotated update), travanj 2005., http://www.cisg.law.pace.edu/cisg/biblio/liu6.html, preuzeto 6. IV. 2020.; Garro, A. M.: Comparison between provisions of the CISG regarding exemption of liability for damages (Art. 79.) and the counterpart provisions of the UNIDROIT Principles (Art. 7.1.7.), Pace Law School Institute of International Commercial Law, 2005.; Nicholas, B.: „Impracticability and Impossibility in the U.N. Convention on Contracts for the International Sale of Goods“, u: Galston \& Smit (ur.), International Sales: The United Nations Convention on Contracts for the International Sale of Goods, 1984., str. 5-1 do 5-24. 
konvencije smatraju se dijelom nacionalnog prava, pa je (ako stranke žele primjenu nacionalnog prava) njihovu primjenu u ugovorima s prekograničnim elementom potrebno eksplicitno isključiti.

Većina spomenutih ugovora najčešće sadrži klauzulu o višoj sili (force majeure) koja može imati različite oblike. Moguće je da se samo općenito referira na višu silu, da se navode primjeri događaja koji se mogu smatrati višom silom ili se pak navodi iscrpna lista takvih događaja (numerus clausus). U pravilu, klauzula o višoj sili oslobađa stranku odgovornosti za vrijeme trajanja više sile. Međutim, mnoge klauzule uključuju i obvezu stranke da poduzme svaki razuman napor da bi prevladala prepreke koje su rezultat okolnosti koje se mogu smatrati višom silom. Upravo iz tog razloga klauzule o višoj sili potrebno je tumačiti od slučaja do slučaja, uzimajući pri tom u obzir i značenje jezične formulacije klauzule, opću alokaciju rizika između ugovornih stranaka te sveobuhvatne okolnosti slučaja. ${ }^{21}$

O značenju i tumačenju klauzule o višoj sili posebno je potrebno voditi računa u prekograničnom prometu. Naime, odredbe o višoj sili različitih nacionalnih zakonodavstava, a također i međunarodnih izvora prava na koje se stranke u ugovorima s međunarodnim obilježjem često pozivaju, značajno se razlikuju u svom sadržaju. K tome, nemaju identične mehanizme isključenja ili ograničenja odgovornosti. Jednako tako, čak i tamo gdje su u pitanju prima faciae identični mehanizmi, sudska se praksa može razlikovati.

S ciljem pokušaja utvrđivanja mogućnosti pozivanja na COVID-19 kao na višu silu u ugovorima vezanim uz organizaciju sportskih natjecanja, u daljnjem tekstu najprije ćemo prikazati mogućnost pozivanja na višu silu u švicarskom pravu, te praksu Arbitražnog suda za sport, kao najčešću varijantu. Potom ćemo se osvrnuti na klauzulu o višoj sili u nekim drugim nacionalnim zakonodavstvima i njihovoj sudskoj praksi i na mogućnost da COVID-19 bude proglašen višom silom.

\section{VIŠA SILA U ŠVICARSKOM PRAVU I PRAKSI ARBITRAŽNOG SUDA ZA SPORT}

Viša sila nastaje najčešće djelovanjem prirodnih događaja koji proizvode određene pravne učinke. ${ }^{22}$ Budući da prirodne događaje i njihove pojavne oblike, koje je moguće kvalificirati kao višu silu, nije moguće unaprijed definirati, ne čudi činjenica da se zakonodavci rijetko odlučuju na eksplicitnu definiciju tog pojma. Češća je varijanta zakonsko definiranje sadržaja pojma više sile, na način da se navode obilježja pojma, kao što su: građanskopravne posljedice (nemogućnost ispunjenja obveze i nastanak štete), vanjski uzrok događaja (nedostatak uzročne veze između događaja i osobe koja se na njega poziva), nepredvidivost (da nije bilo moguće pretpostaviti mogućnost nastupanja događaja), atipičnost (da se

${ }^{21}$ Ambrose, C.: „Force Majeure in International Contracts - The English Law Perspective“, Bus. L. Int'l 2003., str. 237-238.

22 Karakter više sile mogu poprimiti i određene društvene pojave, primjerice rat, lock-out, embargo itd. 
radi o događaju koji nastupa izuzetno odnosno iznimno rijetko) i neotklonjivost/ nesavladivost (da se njegovo nastupanje nije moglo spriječiti nikakvim mjerama ili sredstvima.). ${ }^{23}$ Kao posljedica podjele građanskopravne odgovornosti na objektivnu i subjektivnu, i odgovornost za štetu nastalu uslijed više sile može biti objektivna ili subjektivna. ${ }^{24}$

U pravima koja polaze od objektivne odgovornosti (odgovornost bez krivnje, odgovornost po načelu causae) ne uzima se u obzir ponašanje subjekta u odnosu na događaj (subjektivni element), nego samo objektivne činjenice vezano uz nastanak i djelovanje događaja na kojega se subjekt poziva. ${ }^{25}$ Prednost je ove vrste odgovornosti što se naglasak stavlja na atipičnost događaja. Uz to se traži da je događaj vanjski i neotklonjiv što je ponekad vrlo teško utvrditi, osobito kad su u pitanju fizičke osobe. ${ }^{26}$

U pravima koja polaze od subjektivne odgovornosti (odgovornosti po načelu krivnje, culpae) naglasak je na ,ponašanju subjekta u vezi s okolnostima na koje se on poziva kao na događaj više sile“ ${ }^{27}$ Stoga će se višom silom smatrati ,onaj događaj koji se ni uz maksimalnu pažnju osobe nije mogao predvidjeti niti spriječiti““.28

Postoje i prava (primjerice hrvatsko) koja prihvaćaju mješovito, objektivnosubjektivno rješenje. Takva prava naglasak stavljaju na atipičnost $i$ vanjsko porijeklo događaja (što su temeljna obilježja objektivne odgovornosti), ali uzimaju u obzir i ponašanje subjekta u odnosu na nepredvidivost i nesavladivost događaja te odsustvo njegove krivnje (subjektivne elemente). ${ }^{29}$

\section{Viša sila u švicarskom pravu}

$\mathrm{S}$ obzirom na to da je većina međunarodnih sportskih federacija registrirana u Švicarskoj, te da njihovi statuti i pravila uglavnom supsidijarno upućuju na švicarsko pravo, za sva pitanja koja ne normira lex sportiva bit će mjerodavno švicarsko pravo. U praksi je to popunjavanje pravnih praznina švicarskim pravom relativno rijetko, međutim u okolnostima vezanima uz epidemiju COVID-a 19 oslanjanje na odredbe švicarskog prava bit će prema svim očekivanjima znatno češće, neovisno

23 Tako: Katsivela, M.: „Contracts: Force Majeure Concept or Force Majeure Clauses“, 12(1) Uniform Law Review, 2007., str. 101-120.

24 Ačanski, T.: „Teorija shvaćanja o pojmu više sile“, Zbornik radova Pravnog fakulteta u Novom Sadu, br. XI., 1977., str. 144-155.

25 Matijević, op. cit., str. 2.

26 Vedriš, M., Klarić, P.: Građansko pravo, Narodne novine, 1998., str. 563-564. Tako će se npr. željeznička nesreća do koje je došlo zbog potresa smatrati višom silom jer je događaj vanjski i atipičan. Međutim, željeznička nesreća do koje je došlo zbog nesvjestice strojovođe neće se smatrati višom silom jer se takav događaj ne smatra vanjskim i objektivno neotklonjivim.

27 Matijević, B.: Viša sila u obveznom pravu, IUS-INFO, 22. VIII. 2017., str. 2.

28 Vedriš/Klarić, op. cit., str. 564. Znači da bi po pravu koje se opredijelilo za subjektivnu odgovornost nesvjestica strojovođe bila priznata kao viša sila.

29 Ačanski, op. cit., str. 734. 
o tome hoće li se odnosnim sporom baviti Arbitražni sud za sport ${ }^{30}$ ili švicarski državni sudovi.

Budući da se temelji na načelu striktnog poštovanja načela pacta sunt servanda ${ }^{31}$ švicarsko pravo ne sadrži eksplicitnu klauzulu o višoj sili, međutim, sadrži odredbu na koju se moguće pozvati u vezi s događajima koji se mogu kvalificirati kao viša sila. To je odredba čl. 119. švicarskog Građanskog zakonika, ${ }^{32}$ koja navodi kako će se „smatrati da je obveza prestala (extinguished) kad njezino izvršenje postane nemoguće uslijed okolnosti koje nije moguće pripisati dužniku““. ${ }^{33}$ Odatle slijedi da švicarsko pravo ne dopušta izmjenu ugovora nego samo prestanak, da je uvjet prestanka ugovora, zapravo, kad izvršenje obveze postane nemoguće te da švicarsko pravo prihvaća koncept subjektivne odgovornosti, tj. da odgovornost u odnosnom slučaju ovisi, između ostalog, o ponašanju dužnika.

Praksa švicarskog Vrhovnog suda pokazuje kako je uspješno pozivanje na čl. 119. prilično teško. Poznat je slučaj u kojemu je Vrhovni sud odlučivao o prestanku ugovorne obveze vezane uz izgradnju nuklearne elektrane zbog nemogućnosti nastavka gradnje uzrokovane odlukom švicarskog Saveznog vijeća o embargu na izvoz. ${ }^{34}$ Naime, iako je prihvatio tvrdnju izvođača da je izvršenje njegove obveze uslijed embarga postalo nemoguće, Sud je odlučio da nije moguće primijeniti čl. 119. švicarskog Građanskog zakonika, uz obrazloženje da je riječ o kompaniji čije su aktivnosti vezane uz nuklearni sektor, pa je izvođač mogao znati da uvijek postoji mogućnost embarga. ${ }^{35}$

Međutim, uzimajući u vidu načela sadržana u čl. 373. st. 2. švicarskog Građanskog zakonika, švicarski je Vrhovni sud prepoznao i prihvatio činjenicu kako je moguće da se od trenutka sklapanja ugovora okolnosti toliko radikalno promijene pa tako ugrožavaju ugovorni ekvilibrij, čak i ako ne postoje zakonski razlozi za prestanak ugovora (čl. 352., 373., 545.). ${ }^{36}$ Sukladno postojećoj praksi, kriteriji koji upućuju na pravno relevantne promijenjene okolnosti i omogućuju primjenu doktrine rebus sic stantibus jesu: promjena okolnosti koja dovodi do poremećaja pravne osnove, nepredvidljivost promjene, implicitno ili eksplicitno

30 Čl. R45 CAS CODE u odnosnu na arbitražni postupak te čl. R58 CAS Code u odnosu na postupak po žalbi.

31 Kadner Graziano, T.: Comparative Contract Law: Cases, Materials and Exercises, Edward Elgar Publishing, 2019., str. 50.

32 Engleski prijevod švicarskog Građanskog zakonika dostupan je na https://www.wipo.int/edocs/ lexdocs/laws/en/ch/ch310en.pdf, preuzeto 15. IV. 2020.

33 Švicarski Savezni sud u predmetu 2C_579/2011: „Il y a force majeure en présence d'evénements extraordinaires et imprévisibiles qui survennient en dehors de la sphère d'activité de l'intéressé et qui s'imposent à lui de façon irrésistiblé“ (u slobodnom prijevodu na hrvatski: „Do više sile dolazi u prisutnosti izvanrednih i nepredvidivih događaja koji se zbivaju izvan sfere djelatnosti dotične osobe i koje ta osoba nije u mogućnosti izbjeći i").

34 Vidi odluku švicarskog Vrhovnog suda u predmetu BGE 111 II 352.

35 Vidi: Covid-19 - force majeure: Swiss law, CAS jurisprudence, and the jurisprudence of other sports tribunals, https://www.morgansl.com/en/latest/covid-19-outbreak-force-majeure-swiss-law-casjurisprudence-jurisprudence-other-sports-tribunals, preuzeto 13. IV. 2020.

36 BGE 97 II 398, BGE 68 II 173. Vidi: Rauh, T.: „Legal Consequences of Force Majeure under German, Swiss, English and United States Law“, 25 Dev. J. Int'l Law \& Pol'y 151, 1996., str. 154. i tamo navedeni autori. 
neprihvaćanje rizika od takve promjene, neskrivljeno ponašanje stranke koja se na promijenjene okolnosti poziva te značajan poremećaj ekvivalencije prestacija. ${ }^{37}$ U takvim bi slučajevima inzistiranje na opstanku ugovora, zbog nepravde koju predstavlja prema ugovornoj stranci, bilo protivno načelu savjesnosti i poštenja. ${ }^{38}$ Druge bi opcije bile prihvaćanje relativne nemogućnosti ispunjenja ugovora uslijed okolnosti koje nije moguće pripisati dužniku, ili analogna primjena prava na raskid odnosnog ugovora, kako je omogućeno u slučaju nekih ugovora. Ipak, s obzirom na načelni stav švicarskog zakonodavca prema izuzecima od obveze ispunjenja ugovora, prestanak ili izmjena ugovora zbog promijenjenih okolnosti, ${ }^{39}$ a također i primjena čl. 373. st. 2. švicarskog Građanskog zakonika na druge vrste ugovora, trebala bi biti iznimno restriktivna. ${ }^{40}$

\section{Viša sila u praksi Arbitražnog suda za sport}

Javno dostupne odluke Arbitražnog suda za sport (CAS) pokazuju da se pitanjem više sile Sud bavio u više navrata i u različitim kontekstima. Iako broj takvih odluka nije velik, ipak je moguće tvrditi da pristup koji je CAS zauzeo u odnosu na navedenu problematiku ima mnogo sličnosti s pristupom državnih sudova civilnog pravnog kruga.

Naime, jurisprudencija CAS-a pokazuje tradicionalno strogi test za utvrđivanje više sile, pa je tako „okolnosti koje upućuju na višu silu potrebno tumačiti restriktivno, s obzirom da viša sila predstavlja izuzetak u odnosu na obvezujuću snagu ugovora" ". ${ }^{4}$ Sukladno odluci u predmetu Dnipro v. Football Federation of Ukraine (FFU), da bi CAS utvrdio kako se radi o višoj sili, moraju biti kumulativno ispunjeni sljedeći uvjeti: „(i) postojanje neizbježne i nepredvidive sile“, (ii) nemogućnost predviđanja i sprječavanja takve sile“, (iii) ,,sila koja ne ovisi o volji i aktivnosti fizičke ili pravne osobe“" ${ }^{42} \mathrm{U}$ navedenom predmetu radilo se o nogometnoj utakmici između Dnipra i FC Chernomoretsa Odesa u osmini finala ukrajinskog Nogometnog kupa koja se trebala odigrati u Odesi, Ukrajina. Međutim, utakmica se nije odigrala jer se Dnipro nije pojavio u Odesi. U svom dopisu Odboru za kontrolu i disciplinu FFU, Dnipro se pozivao na nemogućnost dolaska u Odesu uslijed loših vremenskih uvjeta koji su

37 Vidi oduku švicarskog Vrhovnog suda u predmetu BGE 122 III 97. Vidi i odluke švicarskog Saveznog suda u predmetima ATF 100 II 345 i ATF 111 II 429.

38 Vidi odluke švicarskog Vrhovnog suda u predmetima BGE 93 II 185 i BGE 101 II 17.

39 Vidi oduke švicarskog Vrhovnog suda u predmetima BGE 100 II 345 i BGE 07 II 343.

40 Tako, BGE 122 III 97: „Sukladno dosadašnjoj praksi švicarskog Vrhovnog suda, clausula rebus sic stantibus ... iznimno rijetko dovodi do sudskog raskida ili izmjene ugovora... Takva je mogućnost dopuštena jedino onda kada je odnos između ispunjenja i namjere stranaka, uslijed iznimne i nepredvidive promjene okolnosti, poremećen u tolikoj mjeri da vjerovnikovo inzistiranje na ispunjenju ugovorne obveze predstavlja stvarno lihvarsko iskorištavanje nastalog nerazmjera i stoga očitu zloupotrebu prava."

41 Vidi odluku u predmetu CAS 2006/A/1110 PAOK FC v. UEFA, 25. VIII. 2006. (operativni dio od 13. VII. 2006.)

${ }^{42}$ Vidi odluku u predmetu CAS 2013/A/3471 Dnipro v. Football Federation of Ukraine (FFU), 16. VI. 2014. (operativni dio od 24. III. 2014.) isto i: CAS 2018/A/5537 Zamalek Sporting Club v. FIFA, 31. X. 2018. 
onemogućili avionski prijevoz. Također je tvrdio da nije ostalo dovoljno vremena za organizaciju prijevoza vlakom, a da zbog vremenskih uvjeta niti prijevoz autobusom nije bio siguran. Međutim, Odbor je utvrdio da je bilo dovoljno vremena za organizaciju kopnenog prijevoza. S obzirom na to da je i Žalbeni odbor potvrdio ovu odluku, Dnipro je pokrenuo postupak pred CAS-om. CAS je također utvrdio da se u odnosnom slučaju nije radilo o višoj sili, jer nije postojala objektivna i nepredvidiva zapreka, koja bi prijevoz učinila nemogućim, te da se ne može govoriti o višoj sili u situaciji u kojoj bi pravovremeni polazak omogućio slijetanje igrača u mjesto održavanja utakmice prije pogoršanja vremenskih uvjeta.

Prema javno dostupnim odlukama, navedeni uvjeti dosad su bili ispunjeni samo u jednom slučaju, i to u predmetu Alexandria Union Club v. Sánchez \& Cazorla. ${ }^{43}$ $\mathrm{U}$ navedenom predmetu radilo se o radnopravnom sporu između egipatskog nogometnog kluba i dvaju trenera, tj. o prijevremenom prekidu ugovora o radu trenera prouzročenog političkim događanjima u Egiptu 2012. godine. U svojoj odluci CAS je utvrdio da je ,građanski rat u Egiptu događaj koji se može smatrati višom silom, odnosno događajem koji je izvan kontrole stranaka, što stranke nisu mogle razumno izbjeći ili prevladati i što nije moguće pripisati niti jednoj stranci. U takvim okolnostima arbitar pojedinac smatrao je kako su događaji koji su doveli do okončanja sezone 2012/2013, i koji su se stvarno dogodili 1. travnja 2013. godine, spriječili tužitelja (klub) u izvršavanju ugovornih obveza. Slijedom navedenog, počevši od 1. travnja 2013. godine, tužitelj (klub) je oslobođen svih daljnjih ugovornih obveza" (toč. 80.).

O postojanju ili nepostojanju više sile, CAS je odlučivao i u nekim drugim predmetima, ali nije utvrdio postojanje više sile, jer stranka, koja se na nju pozivala, nije uspjela dokazati postojanje više sile. ${ }^{44}$ Tako je u predmetu Ülker ${ }^{45}$ utvrdio

43 CAS 2014/A/3463 \& 3464 Alexandria Union Club v. Sánchez \& Cazorla, 26. VIII. 2014. S obzirom na to da je nogometna sezona 2012/2013 okončana u travnju 2013., te da su plaće kasnile, treneri su izjavili jednostrani raskid ugovora. Prema navodima kluba, klub je uspio naći novog trenera koji bi radio pro bono, a dotadašnjim trenerima ponudio isplatu čekom, no oni su tražili isplatu u gotovini. Kako u tom momentu klub nije raspolagao gotovinom, usuglašen je novi rok za isplatu koji također nije ispoštovan. U međuvremenu klub je na svojoj web-stranici objavio da raskida ugovor s glavnim trenerom i angažira novog trenera. Na zahtjev dotadašnjih trenera da požuri s izjavom o raskidu ugovora klub je zatražio još vremena, ali je potom javno pustio objavu o novom treneru. Dotadašnji treneri najprije su povredu ugovornog odnosa prijavili lokalnoj policiji i zatražili isplatu, a potom pokrenuli postupak pred sucem Odbora za status igrača FIFA-e, koji je utvrdio da se ponašanje kluba može smatrati izjavom raskida ugovora o radu te da je klub dužan isplatiti sve zaostale plaće iz ugovora o radu obama trenerima. Klub je potom pokrenuo postupak pred CAS-om, koji je najprije konsolidirao postupke, a potom uzeo u razmatranje navode stranaka. Klub je tvrdio: da su treneri jednostrano i bez valjanog razloga raskinuli ugovore s obzirom na to da je klub sve dotada uredno ispunjavao svoje obveze; da je pogrešno utvrđeno da je klub taj koji je raskinuo ugovore jer da klub niti nema vlastitu web-stranicu pa nije niti mogao javno objaviti raskid; da je objava bila na osobnoj web-stranici predsjednika Upravnog odbora kluba te da se radi o njegovim osobnim stavovima; da su treneri iskoristili traženu odgodu zbog nemogućnost kluba da ih isplati u gotovini da stvari okrenu u svoju korist te da je odlazak na policiju bio protiv pravila FIFA-e. Treneri su tvrdili suprotno, s naglaskom na okolnost da su sporne objave bile u svim egipatskim medijima te da ni na koji način nisu povrijedili pravila FIFA-e.

44 Baš kao i pred civilnim sudovima, teret dokaza pred CAS -om je na stranci koja se na odnosni dokaz poziva. CAS/2007/A/1380 MKE Ankarangücü Spor Külübu v. S., 11. VI. 2008.; CAS 2015/A/3909 Club Atlético Mineiro v. FC Dynamo Kyiv, 2. X. 2015.

45 CAS 2002/A/388 Ülker Sport/Euroleague, 10. IX. 2002. 
da „prikladno opravdanje“ (suitable justification) nije moguće izjednačiti s višom silom, jer je posljedica više sile nemogućnost ispunjenja obveze, dok ,prikladno opravdanje" predviđa manje od toga (nemogućnosti)" (toč. 5.).

U predmetu Atlético Mineiro ${ }^{46}$ CAS je još jednom potvrdio kako koncept više sile u praksi Arbitražnog suda ,predstavlja već dobro razrađenu doktrinu, koja uključuje postojanje objektivne zapreke, izvan kontrole odnosnog dužnika, koja je nepredvidiva i kojoj se nije moguće oduprijeti, a izvršenje obveze čini nemogućim. ... te zato uvjete za utvrđivanje postojanja više sile treba tumačiti restriktivno, s obzirom na to da viša sila predstavlja izuzetak od obvezujuće snage ugovora" (toč. 1. operativnog dijela Odluke). Također je zaključio kako pravno načelo factum principis, koje uključuje „situaciju u kojoj se država, zbog različitih razloga i javnog interesa, upliće u privatnopravne odnose, mijenjajući tako njihov učinak i destabilizirajući već uspostavljene pravne odnose“ (toč. 65.), ne može biti temelj pozivanja na višu silu u situaciji za koju je odgovoran sam dužnik (toč. 71.).

Konačno, i u predmetima Zamalek podnositelji zahtjeva nisu uspjeli dokazati postojanje više sile. Tako u predmetu Zamalek ${ }^{47}$ iz 2016. godine, vezano uz jednostrani raskid ugovora o radu (igranju) od strane kluba, klub nije uspio dokazati da suspenzija egipatske nogometne lige predstavlja višu silu, uslijed koje bi situacija u kojoj je klub obvezan ispuniti svoje ugovorne obveze prema igraču, za njega predstavljala prekomjeran teret. U predmetu Zamalek $^{48}$ iz 2018. godine, igrač je, u suglasnosti s klubom, raskinuo ugovor o igranju iz opravdanih razloga, međutim, klub nije u dogovorenim rokovima ispunio financijsku svoju obvezu. CAS je utvrdio da podnositelj zahtjeva (klub) nije uspio dokazati da financijske restrikcije koje su uveli Središnja banka Egipta i egipatska nadležna tijela, te zapljena klupskog računa, predstavljaju apsolutnu zapreku isplati dugovanja igraču, te da stoga takve poteškoće ili nedostatak financijskih sredstava ne mogu biti opravdanje za neispunjavanje ugovornih obveza. ${ }^{49}$

\section{VIŠA SILA U DRUGIM NACIONALNIM ZAKONODAVSTVIMA}

\section{Viša sila u francuskom pravu}

Kako korijeni klasičnog koncepta više sile potječu iz Napoleonova Code Civila, ne čudi da su se ranija zakonodavna rješenja u mnogome podudarala s izvornima. Stav ranijeg francuskog prava mogao bi se opisati i kao pomalo ekstreman, jer niti

46 CAS 2015/A/3909 Club Atlético Mineiro v. FC Dynamo Kyiv, 2. X. 2015.

47 CAS 2016/A/4852 Zamalek Sporting Club v. Karim Alhassan, 13. X. 2017.

48 CAS 2018/A/5779 Zamalek Sporting Club v. FIFA, 31. X. 2018.

49 Isto i u predmetima CAS 2016/A/4402 Pathrakikos FC v. FIFA, 20. 9. 2016. (toč. 40.); CAS 2014/A/3533 Football Club Metalurg v. UEFA 9. IX. 2014. (toč. 59.); CAS 2005/A/957 Club Atlético Mineiro v. FIFA, 23. III. 2006. (toč. 24.). 
civilno a niti trgovačko pravo nisu bili skloni iznimkama od obveze ispunjenja ugovora zbog promjena okolnosti koje znatno otežavaju ispunjenje ugovora. Načelo pacta sunt servanda prevladavalo je u odnosu na načelo rebus sic stantibus, ${ }^{50}$ pa su u slučaju da ugovor ne sadrži izričitu odredbu, kojom se normira utjecaj promijenjenih okolnosti, ugovorne stranke bile dužne ispuniti svoje činidbe, bez mogućnosti naknadne prilagodbe obveza iz ugovora. Sud nije bio ovlašten procjenjivati okolnosti u kojima su se stranke našle, niti prilagođavati uvjete ugovora novonastalim okolnostima u cilju postizanja pravičnog rješenja. Isključenje odgovornosti u slučaju neispunjenja građanskih ugovora bilo je moguće jedino u slučaju više sile (force majeure) i slučaja (cas fortuit). ${ }^{51}$

Međutim, prema odredbama „,noveliranog“ francuskog Građanskog zakonika ${ }^{52}$ isključenje odgovornosti u slučaju neispunjenja građanskih ugovora moguće je i u slučaju više sile i u slučaju promijenjenih okolnosti. Da bi, u slučaju više sile (force majeure) dužnik bio oslobođen odgovornosti za neispunjenje ugovorne obveze, moraju se kumulativno ispuniti tri uvjeta (čl. 1218.): događaj mora biti nesavladiv (dakle i izvanjski - izvan ugovorne kontrole odnosne stranke) ${ }^{53}$ nepredvidiv u vrijeme zaključenja ugovora, i neizbježan. ${ }^{54}$ Samo u navedenom slučaju stranke se mogu osloboditi obveze naknade štete. Pri tome nije bitno radi li se o obligaciji sredstva (obligations de moyens), gdje dužnik mora poduzeti sve što je u njegovoj moći kako bi ostvario ciljani rezultat, ali nije vezan rezultatom, ili o obligaciji cilja (obligations dé resultat) koja uključuje obvezu postizanja određenog rezultata. ${ }^{55}$ U odnosu na nesavladivost i nepredvidivost događaja kod obligacija sredstva, objektivnost je zamijenjena subjektivnim kriterijem, tj. od stranke se traži „,da uz primjenu dužne pažnje nije bila u stanju taj događaj predvidjeti, odnosno izbjeći ili savladati“ ${ }^{56}$ Ipak, praksa pokazuje rigidan i neujednačen pristup, jer u određenim slučajevima prihvaća samo apsolutnu nepredvidivost, pa sama mogućnost nekog budućeg događaja, izvedena iz prošlih događaja, bez obzira na to kako daleki i

50 Vidi čl. 1134. Građanskog zakonika prije izmjena i dopuna iz 2016. godine, www.legifrance.gouv. fr $>$ version $>$ file $>$ Code_22. Više o tome: Rimke, J.: Force majeure and hardship: Application in international trade practice with specific regard to the CISG and UNIDROIT Principles of International Commercial Contracts, str. 6. https://www.cisg.law.peace.edu/cisg/biblio/rimke.html, preuzeto 6. III. 2020.

51 Vidi čl. 1148. ranijeg Građanskog zakonika.

52 Izmijenjen i dopunjen Uredbom od 10. veljače 2016. godine, https://www.trans-lex.org/601101/_/ french-civil-code-2016/, preuzeto 15. II. 2020. Vidi: Thibierge, L.: „Force Majeure and Its Effects“, Int'l Bus. L. J. 2017., str. 603-617.

53 Dakle, neispunjenje obveze dobavljača ili suradnika ugovorne stranke istu ne oslobađa odgovornosti.

54 Očito je da ovakva definicija nije u skladu sa zaključcima Kasacijskog suda od 14. travnja 2016. koja se temelji na dva stupa: nepredvidivost i nesavladivost. Upravo takav koncept sudu je, u odnosnom predmetu, omogućio priznavanje dužnikove bolesti kao više sile. U odnosu na koncept primijenjen od strane Kasacijskog suda, trostupanjski koncept uveden Uredbom iz 2016. godine predstavlja povratak na staro. Više o tome vidi u: Thibierge, op. cit., str. 605-606.

55 Terré, F.; Lequette, Y.; Simpler, Ph.: Les obligations, Dalloz-Sirey, 2009., str. 582; Malaurie, Ph.; Aynès, L.; Stoffel-Munck, Ph.: Les obligations, Defrénois, Paris, 2011., str. 499.

56 Ibidem. 
Izv. prof. dr. sc. Ines Medić: Učinak COVID-a 19 na prekogranične ugovore vezane uz organizaciju... Zbornik radova Pravnog fakulteta u Splitu, god. 58, 1/2021, str. 121-150

beznačajni bili, može implicirati predvidivost ${ }^{57}$ dok se u drugim slučajevima zadovoljava i relativnom predvidivosti. ${ }^{58}$

Pravne posljedice više sile kod obje su vrste obligacija iste, u slučaju trajne nemogućnosti ugovor prestaje eo ipso, a stranke se oslobađaju svojih obveza pod uvjetima predviđenim odredbama čl. $1351 .{ }^{59}$ i $1351 .-1 .{ }^{60} \mathrm{U}$ slučaju privremene nemogućnosti, dužnik je oslobođen svoje obveze samo za vrijeme trajanja nemogućnosti. ${ }^{61}$ Pri odlučivanju o sudbini ugovora francuski će sudovi u pravilu voditi računa i o praktičnim posljedicama više sile (potpuna ili djelomična nemogućnost), a također i o vremenskim odrednicama nemogućnosti (privremena ili trajna), pa je osim raskida moguća i odluka o izmjeni ugovora. ${ }^{2}$ Vjerovnik nema pravo na izvansudski raskid ugovora, osim ako same stranke nisu drugačije ugovorile, međutim sudska praksa pokazuje da se to u određenim slučajevima ipak dopušta. Primjerice, u slučaju da „ozbiljnost ponašanja jedne ugovorne strane opravdava jednostrani raskid ugovora od strane druge stranke" ${ }^{63}$ Izvansudski raskid ugovora nije dopušten u slučaju privremene nemogućnosti. ${ }^{64}$ Ako stranke dispozicijom volje odstupe od rješenja navedenih u Građanskom zakoniku, ugovorne odredbe imaju prednost. ${ }^{65}$

Tek izmjenama i dopunama iz 2016. godine, u francusko je ugovorno pravo uveden i institut promijenjenih okolnosti. Tako je dodan čl. 1195. koji normira

57 Primjerice, Odlukom od 9. travnja 1962. Conseil d'Etat utvrdio je da je s obzirom na to da se posljednja poplava na tom području dogodila prije 69 godina, ponovna mogućnost poplave bila predvidljiva. U predmetu iz 1970. godine, sud je presudio da je lavina koja je pogodila svjetski poznato skijalište Val d'Isere bila predvidiva, s obzirom na to da ih je prije 50 već pogodila lavina.

58 Primjerice, u slučaju oružane pljačke hotela u Saint-Tropezu gdje je sud presudio da nije riječ o nepredvidivom događaju iako hotel nikada ranije nije bio opljačkan jer je riječ o hotelu koji ugošćuje uglavnom iznimno bogatu klijentelu. Više vidi u: Kokorin, I., van der Weide, J.: „Force Majeure and Unforseen Change of Circumstances. The Case of Embargoes and Currency Fluctuations (Russian, German and French approaches)“, Russian Law Journal, Vol. III, Issue 3, 2015., str. 26.

59 U slobodnom prijevodu: „Nemogućnost izvršenja ugovorne obveze dužnika oslobađa odgovornosti u mjeri u kojoj ta nemogućnost proizlazi iz više sile i konačna je, osim ukoliko nije prethodno pristao snositi rizik događaja ili je prethodno bio obaviješten o dužnosti ispunjenja svoje obveze."

60 U slobodnom prijevodu: „Ako je nemogućnost izvršenja ugovorne obveze rezultat gubitka dugovane stvari, dužnik koji je prethodno bio obaviješten o dužnosti ispunjenja svoje obveze se još uvijek može osloboditi odgovornosti ako dokaže da bi do gubitka stvari svejedno došlo i da je ispunio svoju obvezu. Međutim, sva prava i potraživanja vezana uz, navedenu stvar mora prenijeti na vjerovnika.“

61 Iako ima i drugačijih tumačenja. Vidi: Thibierge, op. cit., str. 614.

62 U doktrini se kao primjer često spominje slučaj iz davne 1943. godine. Radilo se o ugovoru o najmu osvijetljenog oglasnog prostora na željezničkom kolodvoru. S obzirom na ratne okolnosti, kolodvor tijekom noći nije bio osvijetljen, pa tako ni unajmljeni oglasni prostor. Sud je takve okolnosti priznao za višu silu, ali je umjesto raskida ugovora zbog djelomične nemogućnosti dosudio $20 \%$ smanjenje iznosa najamnine. Više vidi u: Nicholas, B.: „Force Majeure in French Law“, u: McKendrick (ur.), Force Majeure and Frustration of Contract, Informa Law from Routledge, 2013., str. 21., 26.

63 Vidi: Malaurie et al.: op. cit., str. 469.; Laithier, Y.-M.: „Comparative Reflections on the French Law of Remedies for Breach of Contract", u: Cohen, N./McKendrick, E. (ur.): Comparative Remedies for Breach of Contract, Hart Publishing, 2005., str. 103, 119.

${ }^{64}$ Malaurie et al.: op. cit., str. 514.; Bell, J. et al.: Principles of French Law, Oxford University Press, 2008., str. 348 .

65 Vidi: Puelinckx, A. H.: „Frustration, Hardship, Force majeure, imprévision, Wegfall der Geschäftsgrundlage, Unmöglichkeit, Changed Circumstances“, J. Int'l Arb. 47, 1986., str. 50. 
uvjete pod kojima ugovorne stranke, iznimno, mogu zatražiti izmjenu ugovora. Mora se raditi o: okolnostima koje u vrijeme zaključenja ugovora nije bilo moguće predvidjeti, koje izvršavanje ugovora čine pretjerano teškim, te da stranka koja izmjenu traži nije prihvatila rizik od takve promjene okolnosti. Tijekom pregovora o eventualnim izmjenama stranke i dalje moraju ispunjavati svoje ugovorne obveze. U slučaju da druga ugovorna strana odbija izmjenu ugovora ili u slučaju neuspjelih pregovora, stranke se mogu sporazumjeti o raskidu ugovora, od datuma i pod uvjetima koje same odrede, ili mogu sporazumno od suda zatražiti izmjenu ugovora. Ako u razumnom roku ne postignu niti sporazum o pokretanju postupka pred sudom, na zahtjev jedne od stranaka sud će raskinuti ugovor ili ga izmijeniti, od datuma i pod uvjetima koje sam odredi. Pored navedenog, francusko pravo sadrži i niz posebnih zakona koji imaju za cilj ublažiti negativne efekte prouzročene promijenjenim okolnostima kod određenih vrsta ugovora, primjerice o indeksaciji cijena, o promjeni zakupnina itd. ${ }^{66}$

Osim nemogućnosti ispunjenja uslijed više sile, u domeni administrativnih ugovora u teoriji i u praksi prihvaćena je i tzv. „teorija imprevizije“ (imprévision), koja se odnosi na situacije u kojima je ispunjenje ugovora tehnički moguće, ali je uslijed promjene okolnosti iznimno teško ili opterećujuće. Dakle, radi se o mehanizmu kojim je načelo obvezujuće snage ugovora korigirano u slučaju nastupa takvih ekonomskih okolnosti, kakve bi remetile ekonomiju ugovora ${ }^{67}$ Ratio ovog izuzetka moguće je pronaći u javnopravnoj ulozi administrativnih tijela i potrebi osiguranja stabilnosti njihova rada kroz korekciju poremećaja vrijednosti prestacija. ${ }^{68}$

\section{Viša sila u njemačkom pravu}

Njemački pristup utjecaju promijenjenih okolnosti relativno je fleksibilan, ${ }^{69}$ što je i razumljivo s obzirom na to da se temelji na subjektivnoj odgovornosti tj. na načelu krivnje (Verschuldensprinzip).$^{70}$ Iako njemačko pravo ne nudi definiciju pojma više sile (Höhere Gewalt), navedeni se pojam spominje u njemačkom Građanskom zakoniku, ${ }^{71}$ primjerice u čl. 206. (prekid zastare u slučaju više sile).$^{72}$ Njemački Savezni vrhovni sud u svojoj novijoj sudskoj praksi navedeni pojam definira kao

66 Petrić, S.: „Izmjena ili raskid ugovora zbog promijenjenih okolnosti prema novom Zakonu o obveznim odnosima“, Zbornik Pravnog fakulteta Sveučilišta u Rijeci (1991.), v. 28 br. 1, 2007., str. 117. i tamo navedeni autori.

67 Vidi: Puelinckx, op. cit., str. 55.; Petrić, op. cit., str. 114.

68 Petrić, op. cit., str. 117.

69 Jednako tako i: talijansko pravo, nizozemsko pravo, grčko pravo, portugalsko pravo, austrijsko pravo i prava skandinavskih država. Tako: Schwenzer, I.: „Force Majeure and Hardship in International Sales Contracts“ 39 VUWLR 2008., str. 711.

70 Ridder, P., Weller, M.-P.: „Unforseen Circumstances, Hardship, Impossibility and Force Majeure under German Contract Law“, 22 European Review of Private Law, 2014., str. 371., 373.

71 Bürgerliches Gesetzbuch (BGB), engleska verzija dostupna na: https://www.gesetze-im-internet. de/bgb/BJNR001950896.html, preuzeto 15. I. 2020.

72 Prema odredbi navedenog članka, ,zastara se prekida sve dok je vjerovniku onemogućeno provođenje zakona uslijed više sile u posljednjih šest mjeseci zastarnog roka“. 
neočekivani izvanjski događaj koji nije moguće spriječiti niti s najvećom pažnjom koju je u konkretnom slučaju razumno očekivati. ${ }^{73}$ Najvažniji učinci više sile na prava i obveze stranaka, kao što su: nemogućnost (unmöglichkeit), bitna promjena okolnosti na kojima se temelji pravna osnova posla (Wegfall der Geschäftsgrundlage) te krivnja, determinirani su općim načelima njemačkog prava, ponajprije načelom savjesnosti i poštenja (Treu und Glauben).

Sukladno tome, te čl. 275. i 276. st. 2. njemačkog Građanskog zakonika, ako je, nakon zaključenja ugovora, dužnikova obveza bez njegove krivnje postala nemoguća, dužnik se može osloboditi obveze. U tom slučaju niti druga strana nije dužna izvršiti svoju obvezu, osim ako posebne okolnosti slučaja ne govore u prilog drugačijem rješenju. Za potrebe primjene čl. 275. st. 1. BGB nebitno je da li je nemogućnost nastupila odmah ili naknadno, je li objektivna ili subjektivna, djelomična ili potpuna. ${ }^{74}$ Nastupom nemogućnosti ne dolazi do automatskog prestanka ugovora. Stranka je oslobođena naknade štete, ali ugovor ostaje na snazi sve dok vjerovnik ne zatraži njegov raskid. Čl. 326. st. 5. BGB-a predviđena je i mogućnost jednostranog raskida ugovora od strane vjerovnika, i to bez ostavljanja dodatnog roka za ispunjenje ugovornih obveza (Nachfrist) koji se inače traži (čl. 323. st. 1. BGB-a).

Relativno benevolentan poslijeratni pristup njemačkih sudova tumačenju „nemogućnosti“ ispunjenja ugovora u slučaju nepredvidljive i bitne promjene pravne osnove ugovora, u novije su vrijeme zamijenila restriktivna tumačenja, ${ }^{75}$ posebno u ugovorima B2B. ${ }^{76}$ Iznimku čine situacije u kojima je dužnikova obveza postala nemoguća krivnjom njegova zakonskog zastupnika ili podizvođača, pa u tom slučaju dužnik odgovara jednako kao i za vlastitu krivnju. ${ }^{77}$ Njemačka sudska praksa čl. 275. primjenjuje i na slučajeve privremene nemogućnosti, na način da je dužnik oslobođen obveze za vrijeme trajanja te nemogućnosti. ${ }^{78}$ Međutim, često postoji obveza stranke da poduzme sve razumne napore kako bi to stanje prevladala. Mogućnost raskida ugovora zbog privremene nemogućnosti ovisi o „legitimnim interesima vjerovnika i dužnika“".79

73 Smitz, T.: Force Majeure: What to do if?, https://solutions.belfor.com/en-eu/force-majeure-whatdo-if, preuzeto 15. III. 2020.

74 Schlechtriem, P.: Schuldrecht: Allgemeiner Teil, Mohr Siebeck, 2003., str. 151.

75 Poslijeratna doktrine o granici žrtve (Opfergrenze) koja je pojam nemogućnosti tumačila prvenstveno kao ekonomsku nemogućnost, i tvrdila kako dužnika nije moguće tjerati na ispunjenje obveze koja bi za njega predstavljala napor i žrtvu koju stranke koje postupaju u dobroj vjeri nisu mogle razumno očekivati, s vremenom se preobrazila u doktrinu eliminacije (poremećaja) pravne osnove (Wegfall der Geschäftsgrundlage), prema kojoj svaki ugovor ima svoj osnovni cilj koji, u uvjetima različitim od onih koji su postojali u trenutku zaključenja ugovora, nije moguće ostvariti. Vidi: Rimke, op. cit., str. 7.

76 Liu, C.: „Remedies for Non-performace: Perspectives from CISG“, UNIDROIT Principles and PECL, str. 5. http://www.cisg.law.pace.edu/cisg/biblio/chengwei-79.html, preuzeto 6. IV. 2020. Melis, W.: „Force Majeure and Hardship Clauses in International Commercial Contracts in View of the Practice of the ICC Court of Arbitration“", 1 J. Int'l Arb. 231, 1984., str. 213.-221.

77 Čl. 278. BGB.

78 Brunner, C.: Force Majeure and Hardship under General Contract Principles: Exemption for Non-Performance in International Arbitration Kluwer International, 2009., str. 251.

79 Kokorin/van der Weide, op. cit., str. 61. 
Pravo na izmjenu, odnosno raskid ugovora zbog promijenjenih okolnosti, normirano je i čl. 313. BGB-a, koji se primjenjuje u slučajevima kada je činjenična osnova posla toliko poremećena pa stranke, da su u trenutku zaključenja ugovora mogle pretpostaviti takvu promjenu okolnosti, taj pravni posao ne bi zaključile ili bi, eventualno, zaključile neki drugi pravni posao. ${ }^{80} \mathrm{U}$ tom slučaju, moguće je zatražiti izmjenu ugovora, a tek ako to ,nije moguće ili se ne može razumno nametnuti jednoj od stranaka“, dopušten je raskid ugovora. U praksi se navedena odredba kao opće pravilo primjenjuje s oprezom i restriktivno, tj. isključivo u onim slučajevima u kojima bi inzistiranje na ispunjenju obveza iz ugovora bilo očito protivno pravu i pravdi. ${ }^{81}$ Iako su u dosadašnjoj sudskoj praksi njemački sudovi priznavali epidemiju kao višu silu samo u kontekstu turističkog prava, nema razloga isključiti mogućnost da bi trenutna globalna pandemija mogla biti prihvaćena kao jedan od oblika više sile i u odnosu na ostale vrste ugovora. ${ }^{82}$

I u njemačkom pravu ugovorna klauzula o višoj sili ima prednost pred zakonskim rješenjem. Prilikom tumačenja odnosne klauzule njemački će sud uvijek nastojati utvrditi stvarnu namjeru stranaka, čak ako se ona i razlikuje od onoga što je navedeno u ugovoru. ${ }^{83}$

Višu silu njemački sud ne uzima u obzir po službenoj dužnosti, već se zainteresirana stranka na nju mora pozvati, po mogućnosti u pisanoj formi (tzv. izjava o višoj sili).$^{84}$ Teret dokaza je na stranci koja se na višu silu poziva. Iako za davanje izjave zakonom nije predviđen rok, izjavu bi trebalo dati odmah po nastupu relevantnog događaja, osim ako ugovorom nije predviđeno drugačije. U suprotnom bi dužnik mogao odgovarati bez obzira na nastup događaja koji je inače moguće kvalificirati kao višu silu.

\section{Viša sila u engleskom pravu}

Englesko je pravo specifično po tome što inzistira na vrlo striktnom poštovanju načela pacta sunt servanda i u pravilu odbacuje mogućnost prilagodbe ugovora

80 Petrić, op. cit., str. 120.

81 Mazzacano, P.: „,The Treatment of CISG Art. 79 in German Courts: Halting the Homeward Trend“, Nordic Journal of Commercial Law, 2, 2012., http://njcl.fi/2_2012/mazzacano_peter.pdf , preuzeto 1. IV. 2020 .

Vidi: https://www.linklaters.com/en/insights/publications/2020/march/novel-coronaviruscommercial-contracts/novel-coronavirus-impact-on-commercial-contracts/germany.

83 Rimke, op. cit., str. 7.-8.

${ }^{84}$ Smitz, T.: Force Majeure: What to do if?, https://solutions.belfor.com/en-eu/force-majeure-whatdo-if, preuzeto 15. III. 2020. 
promijenjenim okolnostima. ${ }^{85}$ Do 1863. godine, ta je obveza bila apsolutna. ${ }^{86}$ Naime, prema tadašnjim odredbama common lawa niti uvjeti koji su se pojavili nakon zaključenja ugovora, a koji ispunjenje obveze čine nemogućim, ne dovode do oslobađanja od odgovornosti. ${ }^{87}$ Međutim, s vremenom je takav stav ublažen, pa su sudovi to pravilo nastavili primjenjivati samo u onim slučajevima u kojima je ugovorna obveza pozitivna i apsolutna, bez ikakvih uvjeta, bilo izričitih, bilo prešutnih. ${ }^{88}$ To je ujedno i početak doktrine o nemogućnosti ispunjenja ugovora (the doctrine of impossibility) zbog više sile,,$^{89}$ iz koje se naknadno razvila doktrina o frustraciji ugovora (the doctrine of frustration) koja je u engleskom pravu prisutna i danas..$^{90}$

Prema navedenoj teoriji, ugovor može biti frustriran (osujećen) uslijed promijenjenih okolnosti prouzročenih fizičkom ili pravnom nemogućnosti ispunjenja ugovorne obveze, koja dovodi do frustracije ugovora (otpadanja pravne osnove posla), na način da bi održavanje takvog ugovora na snazi zapravo značilo novi ugovor ${ }^{91}$ Stoga, u slučaju frustracije ugovora, ne postoji mogućnost prilagodbe ugovora novim okolnostima, isti prestaje eo ipso. Recentna sudska praksa pokazuje da su engleski sudovi relativno neskloni odlučiti da je riječ o frustraciji ugovora, ${ }^{92}$ osim ako se okolnosti doista nisu toliko promijenile da je ispunjenje ugovora fizički ili pravno nemoguće, odnosno da je ugrožena pravna osnova posla i to bez krivnje bilo koje od stranaka. ${ }^{93}$

Sukladno dostupnoj sudskoj praksi, standardni jezik klauzule o višoj sili u pravilu će se odnositi na događaje izvan razumne kontrole bilo koje od stranaka.

85 Iako je riječ o doktrinarno različitim konceptima, promatrana s praktičnog aspekta razlika između objektivne i subjektivne odgovornosti možda je i precijenjena. Naime, u oba scenarija u slučaju više sile dužnik se oslobađa i svoje primarne obveze (ispunjenje ugovora) koja postaje nemoguća i sekundarne obveze, koju predstavlja naknada štete. Nadalje, u oba scenarija teret dokaza je na dužniku, s time da u slučaju objektivne odgovornosti dokazuje postojanje izuzetaka od odgovornosti, a u slučaju subjektivne odgovornosti da na njegovoj strani ne postoji krivnja. Zapravo je jedina razlika u obvezi nadležnog tijela. U prvom slučaju nadležno će tijelo provjeriti postoje li navedeni izuzeci, a u drugom postoji li krivnja na strani dužnika.

86 Vidi: Rimke, op. cit., str. 5.

87 Paradine v Jane 82 KB 1647, Eng. Rep. 897.

88 Rimke, op. cit., str. 5.

89 Tako će se smatrati nemogućim ispunjenje onog ugovora koji ovisi o postojanju neke osobe ili stvari, a u slučaju prestanka postojanja te osobe ili stvari. Više vidi u: Draeta, U.: „Force Majeure Clauses in International Trade Practice“, 5 Int'l Bus. L. J. 547, 1996., str. 548.; Ambrose, op. cit., str. 234-240.

90 Vidi: Puelinckx, A. H.: „Frustration, Hardship, Force majeure, imprévision, Wegfall der Geschäftsgrundlage, Unmöglichkeit, Changed Circumstances“, 1986 J. Int'l Arb. 47, 1986.

91 Schmitthoff, C. M., Adams, J.: Schmithoff's Export trade: the law and practice of international trade, UCLA, 1986., str. 146. Doktrina o frustraciji ugovora veže se uz tzv. Coronation cases (Krell v. Henry [1903] 2 KB 740). Radi se o ugovorima o jednodnevnom najmu stanova čiji je položaj omogućavao pogled na krunidbenu paradu Edvarda VII. Nakon otkaza parade zbog bolesti kralja, najmodavci su tužili zbog neplaćanja najma međutim, sud je presudio da je došlo do frustracije ugovora s obzirom na to da bi pravna osnova takvog posla bila bitno drugačija od one koju su stranke inicijalno imale na umu.

92 Dosada su to utvrdili vezano uz: oduzimanje broda, eksploziju i eksproprijaciju predmeta ugovora od strane strane vlade. Chitty, op. cit., § 23-002 i § 23-021.

93 Liu, C.: Changed Contract Circumstances (2nd edition: Case annotated update), travanj 2005., str. 6., http://www.cisg.law.pace.edu/cisg/biblio/liu5.html, preuzeto 6. IV. 2020. 
Za utvrđivanje događaja koji se mogu smatrati višom silom presudna je precizna formulacija klauzule o višoj sili. ${ }^{94}$ To je osobito važno u slučajevima u kojima će se klauzula o višoj sili tumačiti upućivanjem na jezično tumačenje ugovora umjesto na „opću namjeru“ stranaka. ${ }^{95}$ Ugovorna odredba kojom se samo utvrđuje da se primjenjuju „uobičajene odredbe o višoj sili“ u praksi se smatra ništetnom zbog neodređenosti. ${ }^{96}$ Pri utvrđivanju može li se u navedenom slučaju pozvati na višu silu, sud će razmotriti ,,poslovnu praktičnost“ (commercial practicability), odnosno „teškoće s kojima se susreo tužitelj u trenutačnom cjelokupnom poslovnom kontekstu“", te jesu li ,iste bile dostatne da se tužitelj nađe u poslovno nepraktičnoj situaciji“" ${ }^{97}$ Međutim, ako su stranke navedenom klauzulom obuhvatile samo okolnosti koje ugovor čine ekonomski neodrživim, prema engleskom pravu višom će se silom smatrati isključivo oni događaji koji u cijelosti onemogućavaju (a ne samo otežavaju) izvršenje ugovora.$^{98}$ Prema dostupnoj sudskoj praksi, u engleskom pravu nema mjesta pozivanju na klauzulu o višoj sili u slučaju kad su okolnosti

94 RDC Concrete Pte Ltd v Sato Kogyo (s) Pte Ltd [2007] 4 SLR(R) 413. Chua, W., Ahuja, S.: COVID-19 (Coronavirus), Force Majeure and Construction (Part II) - Outbreak of Disputes? Or Abatement in due course?, http://dentons.rodyk.com/en/insights/alerts/2020/february/20/covid19-forcemajeure-annd-construction--part-ii , preuzeto 20. II. 2020.

95 Coastal (Bermuda) Petroleum Ltd v VTT Vulcan Petroleum SA (the Marine Star (No 2)) [1996] 2 Loyd's rep. 383. Sud je odlučio da se prodavatelj može pozvati na klauzulu o višoj sili da bi se oslobodio odgovornosti prouzročene greškom svog dobavljača jer se radi o ugovoru o kupoprodaji pa nije moguće govoriti o ugovornoj kontroli odnosno odgovornosti odnosnog prodavatelja. Međutim, sud je odlučio da domašaj klauzule o višoj sili ne zahvaća dobavljača prodavatelja jer da navedenu klauzulu (promatranu u svjetlu općih namjera stranaka) nije moguće tumačiti na način da se odnosi na bilo kojeg prodavatelja. Stoga je, u slučaju da prodavatelj želi ograničiti svoju odgovornost za djelovanje i propuste svojih dobavljača potrebno ugraditi odgovarajuću zaštitu u ugovor s odnosnim dobavljačem.

96 British Electrical and Associated Industries (Cardiff) Ltd v Patley Pressings Ltd [1953] 1 W.L.R. 280 .

97 Holcim (Singapore) Pte Ltd v. Precise Development Pte Ltd [2011] 2 SLR 106, Žalbeni sud je razmatrao kako tumačiti klauzulu o višoj sili u odnosu na indonezijsku zbranu izvoza pijeska iz 2007. godine.

98 Lebeaupin v Richard Crispin \& Co [1920] 2 KB 714. Sud je u svojoj odluci suprotstavio zakonske i druge ljudskim aktima uzrokovane zapreke s jedne strane i prirodne nepogode s druge strane te je istaknuo da je potrebno voditi računa o formulaciji klauzule o višoj sili. Naime, ako su stranke navedenom klauzulom obuhvatile samo okolnosti koje ugovor čine ekonomski neodrživim, prema engleskom pravu višom će se silom smatrati isključivo oni događaji koji u cijelosti onemogućavaju (a ne samo otežavaju) izvršenje ugovora. Vidi: Beale, H. (ur.): Chitty on Contracts, Sweet \& Maxwell, 2019., §15-163. U predmetu Seadrill Ghana Operations Ltd v Tullow Ghana Ltd [2018] EWHC 1640, tuženik se pozvao na višu silu izazvanu „moratorijem bušenja nafte“ nametnutim od strane vlade Gane. Tužitelj to nije prihvaćao jer je tvrdio da je prekid ugovora od strane tuženika izjavljen zbog ekonomske neisplativosti uslijed pada cijena nafte. Sud je utvrdio da se proglašenje moratorija od strane države činjenično može smatrati višom silom, međutim, da to nije jedini razlog neizvršenja ugovora te se stoga tuženika ne može osloboditi odgovornosti. Isto i u slučaju Thames Valley Power Ltd. V Total Gas \& Power Ltd [2005] EWHC 2208. 
Izv. prof. dr. sc. Ines Medić: Učinak COVID-a 19 na prekogranične ugovore vezane uz organizaciju... Zbornik radova Pravnog fakulteta u Splitu, god. 58, 1/2021, str. 121-150

relevantnog događaja u sferi ugovorne kontrole prodavatelja, pa čak i kad je riječ o pod-pod-podizvođaču..$^{99}$

U bilateralnim ugovorima samo se stranke mogu pozvati na višu silu. Međutim, u multilateralnim ugovorima koji uključuju više stranaka i lančane odnose situacija je daleko kompleksnija.

\section{Viša sila u hrvatskom pravu}

Iako svoje porijeklo vuče još iz rimskog prava, viša je sila na našem prostoru najprije bila regulirana odredbom \$1447. austrijskog Općeg građanskog zakonika iz 1811. godine, koji eksplicitno ne spominje višu silu, iako je iz teksta odredbe jasno da se na nju referira. ${ }^{100}$ Posebna zakonska odredba prvi je put uvedena čl. 3. st. 2. Uredbe FNRJ, ${ }^{101}$ a zadržana je i u Zakonu o obveznim odnosima iz 1978. koji je 1991. preuzet u hrvatski pravni sustav. ${ }^{102}$

Višu silu kao egzoneracijski razlog, iako ne eksplicitno, prihvaća i današnje hrvatsko pravo. Njezin sedes materiae i dalje je Zakon o obveznim odnosima (ZOO), iz 2005. godine. ${ }^{103}$ Pored temeljnog pravila da (svaka) „obveza prestaje kad njezino ispunjenje postane nemoguće" (čl. 208. st. 1.), te da je teret dokaza postojanja okolnosti koje isključuju njegovu krivnju na dužniku (čl. 208. st. 2.), u odnosu na dvostranoobvezne ugovore, relevantna je odredba čl. 373. st. 1.: „Kad je ispunjenje obveze jedne strane postalo nemoguće zbog izvanrednih vanjskih događaja nastalih nakon sklapanja ugovora a prije dospjelosti obveze, koji se u vrijeme sklapanja ugovora nisu mogli predvidjeti, niti ih je ugovorna strana mogla spriječiti, izbjeći ili otkloniti te za koje nije odgovorna ni jedna ni druga strana, gasi se i obveza druge

99 Great Elephant Corporation v Trafigura Beheer BV (The Crudesky) [2013] 2 All E.R. (Comm) 992, prodavatelj nafte se pozvao na višu silu zbog kašnjenja operatera terminala s ukrcajem nafte na brod kupca uslijed događaja izvan kontrole operatera. Sud je odlučio da nema mjesta pozivanju na klauzulu o višoj sili u slučaju kad su okolnosti relevantnog događaja u sferi ugovorne kontrole prodavatelja, pa čak i kad je riječ o pod-pod-podizvođaču (kao što je u ovom slučaju operater terminala). Neovisno o tome što je klauzula o višoj sili glasila na ,bilo koju stranku“ glavnog ugovora, sud je smatrao da se navedena sintagma zapravo odnosi na ,,bilo koju stranku kojoj je povjereno ispunjenje ugovornih obveza jedne od stranaka“. Navedeni slučaj jasno pokazuje i da englesko pravo ne traži da su okolnosti koje su uzrokovale višu silu nepredvidive, dostatno je dokazati da su navedene okolnosti izvan razumne kontrole (reasonable control) ugovornih stranaka. Tako i u predmetima Channel Island Ferries Ltd v Sealink UK Ltd [1988] 1 Lloyd's Rep 323 i Classic Maritime v Limbungan Makmur [2018] EWHC 2389 (66).

100 „Ako po nenadanom slučaju izgine kakva stanovita stvar, tada se ukida svaka obveza, i ona također, da se nadoknadi vrijednost njezina. Ovo načelo služi i za one slučajeve, kada se radi inog kojeg nenadanog slučaja ne može ispuniti obveza ili dug platiti." Vidi: Vuković, M.: Opći građanski zakonik, Školska knjiga, Zagreb, 1955., str. 478.

101 „Stranke se oslobađaju ugovornih obveza samo uslijed djelovanja više sile. Kao viša sila smatrat će se, osim prirodnih (elementarnih) događaja koji se nisu mogli predvidjeti u času zaključenja ugovora i koji su spriječili njegovo izvršenje, još i: a) ako je izvršenje ugovora bilo uvjetovano uvozom sirovina ili robe iz inozemstva, koji je izostao iz objektivnih teškoća; b) ako je izvršenje ugovora onemogućeno mjerama opće prirode koje su donijeli državni organi u vršenju svoje nadležnosti." Uredba FNRJ od 16. prosinca 1946. o zaključivanju ugovora u privredi, S1. 1. FNRJ, br. 103/46. Za primjere sudske prakse vidi: Matijević, B.: Viša sila u obveznom pravu, IUS-INFO, 22. 8. 2017., preuzeto 22. IV. 2020.

102 Ukaz o proglašenju Zakona o preuzimanju Zakona o obveznim odnosima, NN br. 53/91.

103 Zakon o obveznim odnosima RH, NN br. 35/05, 41/08, 125/11, 78/15, 29/18. 
strane, ...“. Iz navedene odredbe jasno proizlazi da ZOO prihvaća mješovitu teoriju o višoj sili, odnosno da se uz objektivne elemente odgovornosti (atipičnost i vanjsko porijeklo događaja) uzima u obzir i ponašanje stranaka (da odnosni događaj niti jedna ugovorna strana nije mogla spriječiti, izbjeći ili otkloniti). ${ }^{104}$ Isto potvrđuje i sudska praksa. Tako Vrhovni sud RH navodi: „,... kao viša sila (vis maior) razumijeva se onaj vanjski događaj ili pojava koja je po snazi svog djelovanja u toj mjeri jača od samog čovjeka da njezino djelovanje nastupa neovisno od čovjekove volje, jer se ono ni objektivno nije moglo predvidjeti, ni izbjeći niti otkloniti““ ${ }^{105}$ Sukladno st. 2. čl. 373. ZOO-a, u slučaju djelomične nemogućnosti ispunjenja uslijed više sile, druga strana ima pravo zahtijevati razmjerno smanjenje svoje obveze, osim ako djelomično neispunjenje ne odgovara njezinim potrebama u kojem slučaju ima pravo raskinuti ugovor.

Osim zbog više sile, stranka se može osloboditi odgovornosti i zbog slučaja. Osnovni kriterij razlikovanja jest porijeklo događaja. ${ }^{106}$ Za razliku od više sile, gdje se traži da događaj ima izvanjski uzrok i da je potpuno izvan sfere utjecaja osobe koja se na nju poziva, kod slučaja se uzrok nalazi unutar utjecaja stranke koja se na slučaj poziva, ali joj se ne može pripisati u krivnju. Pored toga, mora se raditi o događaju koji je objektivno predvidljiv, koji je savladiv (relativno uklonjiv) te koji je nastupio bez krivnje odgovorne osobe. ${ }^{107}$

Što se drugih egzoneracijskih razloga tiče, hrvatsko pravo tradicionalno prihvaća klauzulu rebus sic stantibus ${ }^{108}$ kao opći institut ugovornog prava. Doduše, iz zakonske odredbe nije posve jasno odnosi li se samo na naplatne ili i na besplatne dvostranoobvezujuće ugovore. ${ }^{109}$ Nije eksplicitno definirano niti odnosi li se i na aleatorne ugovore. ${ }^{110} \mathrm{U}$ svakom slučaju, kako bi se stranka mogla pozivati na promijenjene okolnosti, mora se raditi o okolnostima koje se (u pravilu) nalaze izvan stranaka, ${ }^{111}$ koje su nastale u razdoblju nakon zaključenja ugovora do datuma dospijeća obveze, a dovele su do promjene koja bitno utječe na položaj stranke. ${ }^{112} \mathrm{U}$ praksi

104 Vidi: VSRH, Rev 131/1991-2, od 23. XII. 1992. U navedenom predmetu radi se o oštećenju automobila tužitelja u trenutku kada je njime upravljao tuženik po odobrenju tužitelja, koji je do tada vozio, ali je osjetio umor pa je ustupio automobil tuženiku. Šteta na automobilu uzrokovana je naglim gubitkom zraka iz pneumatika što je uzrokovalo destabilizaciju automobila. Sud je presudio da se okolnost što je u kritičnom trenutku došlo do stradavanja pneumatika, a moguće i do pucanja gume, te posljedično tome slijetanja vozila tužitelja i nastanka štete, ne može pripisati tuženiku već manama i svojstvima vozila za koje odgovara sam vlasnik (u ovom slučaju tužitelj).

105 Vidi: VSRH Rev 930/2009-2., od 31. 1 2012. Doduše, u navedenom predmetu radi se o izvanugovornoj odgovornosti, tj. o prometnoj nesreći izazvanoj smrću vozača (uslijed pretrpljenog srčanog udara) tijekom vožnje. Sukladno (tadašnjem) čl. 177. st. 1. ZOO-A, imatelj opasne stvari (automobil) oslobađa se od odgovornosti.

106 Ačanski, op. cit., str. 732 .

107 Vedriš/Klarić, op. cit., str. 572-573.

108 Više o tome vidi u: Petrić, op. cit., str. 125-128.

109 Vidi: Petrić, op. cit., str. 129-132.

110 Vidi: Petrić, op. cit., str. 133. itd.

111 Može se raditi o prirodnim događajima, društvenim i političkim događajima, mjerama javne vlasti

112 Vidi: VSRH Gzz 44/1991-2, od 17. prosinca 1991. 
će se najčešće raditi o poremećaju uzajamnih prestacija ${ }^{113}$ ili o povećanju troškova ispunjenja činidbe ${ }^{114}$ i sl. Isključeno je pravo stranke pozivati se na promijenjene okolnosti u slučaju da joj ispunjenje obveze nije otežano, ali je dovelo do osujećenja cilja ugovora. Prema odredbama ZOO-a (čl. 369. st. 1.) u slučaju promijenjenih okolnosti, pogođena stranka ima mogućnost ponuditi izmjenu ugovora ili raskid ugovora, pri čemu je izmjena primarno, a raskid podredno pravo stranke. ${ }^{115}$ Nasuprot tome, druga strana ima pravo prihvatiti ili odbiti ponuđenu izmjenu, sama ponuditi izmjenu ili zatražiti raskid ugovora, ali i zahtijevati naknadu pravičnog dijela štete koju trpi zbog prihvaćanja zahtjeva za izmjenu odnosno raskid ugovora, ako dokaže da šteta potječe od nekog uzroka koji se nalazio izvan stvari, a čije se djelovanje nije moglo predvidjeti, ni izbjeći ni otkloniti.

\section{MOŽE LI SE COVID-19 SMATRATI VIŠOM SILOM?}

Temeljno i univerzalno prihvaćeno načelo ugovornog prava jest načelo pacta sunt servanda. Navedeno načelo najbolje reflektira prirodnu pravdu, s jedne strane, i zahtjeve ekonomije, s druge strane, jer vezujući stranku uz njezino obećanje ujedno štiti interese druge strane. ${ }^{116}$ Međutim, u situaciji u kojoj su se nakon zaključenja ugovora okolnosti promijenile u mjeri u kojoj stranke postupajući kao razumne osobe nikad ne bi zaključile takav ugovor, potrebno je dopustiti iznimke. To se osobito odnosi na ugovore s prekograničnim obilježjem koji su, zbog političkog i ekonomskog utjecaja različitih jurisdikcija i inače izloženi većim nesigurnostima.

Iako danas gotovo sva zakonodavstva uzimaju u obzir utjecaj promijenjenih okolnosti (doktrina rebus sic stantibus), uvjeti pod kojima dopuštaju pozivanje na njih, uključujući višu silu, razlikuju se. Primjerice, u common law sustavima odgovornost za neispunjenje je objektivna (iako postoje određeni izuzeci), dok je u državama civilnog pravnog kruga subjektivna. ${ }^{117}$ Jednako tako i posljedice znatno variraju, pa je mogućnost raskida ugovora u common law sustavima u pravilu primarni lijek, a u državama civilnog pravnog kruga smatra se posljednjom opcijom. ${ }^{118}$ Očito je da nemogućnost predviđanja pravnih posljedica više sile vodi velikim rizicima za ugovorne stranke. Stoga je izrazito preporučljivo u ugovor ugraditi preciznu klauzulu o višoj sili. ${ }^{119}$

Većina ugovora o igranju, a također i ugovora o gostovanju (host agreement) koje sportske federacije ili nacionalni sportski savezi sklapaju s organizatorom sportskog natjecanja imaju ugrađenu klauzulu o višoj sili, kojom se dužnik oslobađa

113 Vidi: VTSRH, Pž 160/93, od . 15. VI. 1993.

114 Vidi: VSRH Rev 2521/1995-2, od 4. II. 1996.; VSRH Gzz 44/1991/2, od 17. XII. 1991.

115 Vidi: Petrić, op. cit., str. 142.

116 Rimke, op. cit. str. 2.

117 Perillo, J.: „Force Majeure and Hardship Under the UNIDROIT Principles of International Commercial Contracts“, 5 Tul. J. Int'L. \& Comp., 1997., str. 12.

118 Rauh, op. cit., str. 163.

119 Ibidem, str. 171. 
odgovornosti (za neispunjenje i/ili zakašnjenje) u slučaju događaja koji se može kvalificirati kao viša sila.

U nekima se eksplicitno spominje općenito bolest, ${ }^{120}$ rjeđe je eksplicitno navedena epidemija ili pandemija, ${ }^{121}$ a u nekima se samo generalno poziva na višu silu. ${ }^{122}$ Razlike postoje i u vezi s pozivanjem na druge okolnosti koje bi se mogle okarakterizirati kao viša sila. Tako se skoro svi ugovori pozivaju na „Act of God“123 te djelovanje ili akt vlade, dok samo manji broj eksplicitno spominje embargo ${ }^{124}$ i zatvaranje granica. Razlike su primjetne i u vezi s obvezom obavješćivanja, u odnosu na stranke, rokove i posljedice. Ono što im je zajedničko jest subjektivna odgovornost kao preduvjet oslobađanja od odgovornosti. Dakle, od stranke koja se poziva na višu silu traži se da je poduzela sve što se razumno moglo očekivati kako bi umanjila posljedice više sile. Posljedice se također razlikuju od ugovora do ugovora, u pravilu se isključuje naknada štete i automatski prekid ugovora, te jednostrani prekid ugovora od strane organizatora. Za slučaj spora, uglavnom je predviđena nadležnost Arbitražnog suda za sport ${ }^{125}$ te primjena Kodeksa arbitraže vezane uz sport ${ }^{126}$ ili podredna primjena švicarskog prava, mada i kod toga ima iznimki.

Očito je da sve sportske federacije, u ugovorima s organizatorima sportskih natjecanja, vode računa o mogućem nastupu nepredviđenih okolnosti koje mogu imati utjecaja na ugovorne obveze. Jednako je očito i da su odredbe sadržane u pojedinim ugovorima manjkave i da će postojati potreba za podrednom primjenom mjerodavnog prava. Bez obzira na neupitnu prednost primjene ugovorne odredbe, s obzirom na okolnost da neki ugovori ne spominju niti bolesti niti epidemije, bit će

120 Npr. Ugovor o gostovanju između Međunarodne konjičke federacije i organizatora natjecanja.

121 Npr. Ugovor između međunarodne skijaške federacije i nacionalne skijaške federacije i organizatora natjecanja ili Ugovor kojim se uređuje gostovanje i organizacija velikog master turnira u hokeju itd. Neki ugovori sadrže vrlo zanimljiva rješenja, primjerice Kolektivni ugovor NBA koji sadrži klauzulu o višoj sili koja predviđa mogućnost uskrate plaće igračima zbog bolesti izvan kontrole lige (saveza), uključujući i epidemiju. Vidi: https://www.sportsbusinessdaily.com/Journal/Issues/2020/04/06/ Sports-and-Society/NBA-pay.aspx, preuzeto 13. IV. 2020.

122 Npr. Ugovor s gradom domaćinom za završni turnir UEFA Europskog nogometnog prvenstva 2010/2012, Ugovor o stadionu za završni turnir UEFA nogometnog prvenstva 2010/2012 te Ugovor s hotelom za završni turnir UEFA nogometnog prvenstva 2010/2012, u postupku kandidature za Europsko nogometno prvenstvo.

123 Božji čin, Božje djelo.

124 Npr. Ugovor između međunarodne skijaške federacije i nacionalne skijaške federacije i organizatora natjecanja i Ugovor kojim se uređuje gostovanje i organizacija velikog master turnira u hokeju.

125 Ponekad može biti ugovorena i neka druga arbitraža. Npr. u Ugovoru s gradom domaćinom za završni turnir UEFA Europskog nogometnog prvenstva 2010/12 ugovorena je nadležnost arbitraže u Nyonu. Ugovorom kojim se uređuje gostovanje i organizacija velikog master turnira u hokeju ugovara se nadležnost Odbora za natjecanje Međunarodne skijaške federacije (FIH Competition Committee).

126 Code of Sports-Related Arbitration, na snazi od 1. siječnja 2019. godine. https://www.tas-cas.org/ fileadmin/user_upload/Code_2019_en_.pdf, preuzeto 12. XI. 2019. 
potrebno njihovo tumačenje. ${ }^{127}$ To će se vjerojatno pokazati kobnim kod ugovora s generičkim ugovornim odredbama o višoj sili, jer sudska praksa njihovo tumačenje izbjegava. ${ }^{128} \mathrm{U}$ pravilu se takve odredbe smatraju ništetnim zbog neodređenosti. Također je potrebno jasno navesti uvjete pod kojima će okolnosti koje su klauzulom obuhvaćene kao viša sila, biti dostatne kako bi se dužnik oslobodio odgovornosti. Na primjer, nije isto navodi li klauzula „spriječenost“ ili „,nemogućnost“ (pravnu, ekonomsku) dužnika, jer u slučaju da je klauzulom ugovorena „nemogućnost“" samo „spriječenost“ neće biti dovoljna za oslobađanje dužnika od odgovornosti. Poželjno je klauzulom propisati i učinke više sile na ugovorne obveze stranaka, jer podredna primjena odredaba mjerodavnog prava može omogućavati samo izmjenu, ali ne i raskid ugovora.

Međutim, ne smijemo zaboraviti ni niz drugih ugovora koje organizatori natjecanja sklapaju s trećim osobama u svrhu realizacije preuzetih obveza, a za koje nije nadležan Arbitražni sud za sport, niti mjerodavno švicarsko pravo. Sukladno ranije navedenom, o nastupu i posljedicama više sile u tim ugovorima prosuđivat će se po pravu koje su kao mjerodavno ugovorile stranke.

Imajući u vidu navedeno, odgovor na pitanje utjecaja COVID-a 19 na ugovore o organizaciji sportskih natjecanja postaje nešto određeniji, ali ne i određen. Naime, ako uzmemo u obzir uvjete koji u većini pravnih sustava moraju biti ispunjeni kako bi se stranka mogla pozvati na višu silu, prvo pitanje koje bi se moglo postaviti jest je li riječ o nepredvidivom događaju? Ako se traži apsolutna nepredvidivost, onda bi odgovor bio ne. Tome u prilog govori i činjenica da će organizatori Wimbledona, najstarijeg i ujedno najuglednijeg teniskog turnira na svijetu, od osiguranja naplatiti oko 114 milijuna funti zbog otkazivanja ovogodišnjeg turnira uslijed COVID-a 19. Nakon širenja virusa SARS-a 2003. godine, organizatori Wimbledona plaćaju milijunsko godišnje osiguranje od pandemije. ${ }^{129}$ Međutim, ako je epidemija ili pandemija bila eksplicitno navedena kao viša sila ili je standard predvidivosti niži, onda će se izbijanje COVID-a 19 najvjerojatnije kvalificirati kao viša sila, osim ako je nemogućnost ispunjenja ugovorne obveze posljedica skrivljenog ponašanja dužnika (ako je dužnik u vrijeme sklapanja ugovora mogao ili morao moći predvidjeti nadolazeću epidemiju). Dužnik se na višu silu može pozivati i u slučaju da je odgoda ili otkaz sportskog natjecanja rezultat mjera koje je u svrhu sprečavanja epidemije poduzela vlada, a koje

127 Praksa pokazuje da je korištenje „klauzula po mjeri“ ugovornih stranaka iznimno bitno jer su međunarodni arbitražni tribunali u pravilu suzdržani u uplitanju u ugovorne obveze bez izričitog ovlaštenja sadržanog u samom ugovoru. To stoga što smatraju da su B2B ugovori napisani na način da već uključuju profesionalnu procjenu rizika. Vidi: Polkinghorne, M., Rosenberg, C.: „Expecting the Unexpected: the Force Majeure Clause“, Buss. Law Int'l, Vol. 16, No. 1, 2015., str. 50-51; Augenblick, M., Rousseau, A. B.: „Force Majeure in Tumultuous Times: Impracticability as the New Impossibility“, 13 J. World Investment \& Trade, 2012., str. 59-60.

128 Tradicionalne (boilerplate) klauzule o višoj sili već odavno ne prate suvremeni život. Ni u kom slučaju se ne preporučuje uključiti u ugovor takvu klauzulu s uvjerenjem da se viša sila neće dogoditi. Više o odnosnoj problematici vidi u: Wright, W. C., „Force Majeure Delays“, 26 Constr. Law, 2006., str. 34-35.

129 Više vidi u: Marjanović, V.: Ni koronavirus ih ne može iznenaditi, osiguranje im plaća štetu 114 milijuna funti, https://novac.jutarnji.hr/makro-mikro/ni-koronavirus-ih-ne-moze-iznenaditi-osiguranjeim-placa-stetu-114-milijuna-funti/10203793/, preuzeto 14. IV. 2020. 
u trenutku sklapanja ugovora nije bilo moguće predvidjeti (jer su mjere poduzete prije izbijanja epidemije u toj državi).

Čak i slučajevima u kojima su tijela Međunarodnih sportskih saveza nadležna za donošenje odluka (primjerice Izvršni odbor FIFA-e) proglasila COVID-19 višom silom, ${ }^{130}$ njihove su odluke ograničenog dosega (u ovom slučaju odnose se isključivo na pitanja vezana uz status i transfere igrača) i upitno je hoće li Smjernice imati univerzalnu primjenu (primjerice, hoće li se na njih moći pozivati i one ugovorne stranke koje dolaze iz država u kojima se odnosni sport odvijao normalno).

\section{ZAKLJUČAK}

Globalna nastojanja za sprečavanje širenja COVID-a 19 imala su za posljedicu odgodu ili otkazivanje gotovo svih velikih sportskih događanja u ovoj godini. Odgođen je, primjerice, Euro 2020, Olimpijske i Paraolimpijske igre u Tokiju, maratoni u Londonu i Bostonu, Wimbledon i čitav niz drugih sportsko-zabavnih događanja. Posljedice odgode odnosno otkazivanja variraju od onih blagih, pravno irelevantnih kao što je razočarenje brojnih navijača, do puno ozbiljnijih, s vrlo konkretnim pravnim i financijskim posljedicama. Organizatori natjecanja, sponzori, pružatelji radiotelevizijskih i digitalnih usluga, pružatelji usluga smještaja, različiti prijevoznici i drugi akteri sportsko-zabavnog sektora suočeni su s posvemašnjim slomom svojih brižljivo planiranih aktivnosti, počevši od (vjerojatnog) gubitka vlastitih inicijalnih ulaganja, do gubitka dobiti od očekivanih prihoda. Otkazi i gubitak radnih mjesta šire se poput koncentričnih valova, i sve su glasnija pitanja usmjerena na pravne posljedice situacije u kojoj su se, bez svoje krivnje, našli.

Za očekivati je da će organizatori natjecanja nastojati na svaki način kompenzirati nastalu štetu. Neki će tražiti pomoć od države, a drugi će pokrenuti sudske sporove. U odnosu na članice Europske unije situacija će umnogome ovisiti o Europskoj komisiji. Naime, sve dostupne ublažavajuće mjere (državni zajmovi, garancije, odgoda poreznih i socijalnih davanja) koje su državi na raspolaganju za pomoć sportskom (i drugim) sektorima u svjetlu prava EU-a, mogu se smatrati vrstom državne potpore, ${ }^{131}$ što znači da je njihovo korištenje podložno uvjetima propisanim pravom Unije i prethodnom odobrenju Komisije. Iako je Komisija eksplicitno navela da će s obzirom na krizu izazvanu koronavirusom uvjeti za dodjelu potpora biti znatno fleksibilniji ${ }^{132}$ i dalje nije jasno hoće li potpora biti ograničena isključivo na organizatore natjecanja ili će biti dostupna i pridruženim pružateljima usluga

130 Vidi: smjernice za što sigurniji povratak nogometu, pod nazivom „COVID-19 regulatorna pitanja u nogometu“, od 7. IV. 2020; d donesene u skladu s čl. 27. Pravilnika FIFA-e o statusu i transferima igrača koji predviđa „O pitanjima koja nisu obuhvaćena ovim Pravilnikom i u slučajevima više sile odlučuje Izvršni odbor FIFA-e, čije odluke su konačne“.

131 Vidi: Biondi, A.; Eeckhout, P.; Flynn, J.: The Law of State Aid in the European Union, Oxford Scholarship Online, March 2020; Riedel, P.; Wilson, T.; Cranley, S.: EU State Aid and COVID-19, http:// competitionlawblog.kluwercompetitionlaw.com/2020/03/24/eu-state-aid-and-covid-19/, preuzeto 24. III. 2020 .

132 Vidi: https://ec.europa.eu/competition/state_aid/what_is_new/covid_19.html, preuzeto 3. IV. 2020. 
(npr. sponzorima ili zastupnicima igrača). Ostaje za vidjeti hoće li obećane mjere pozitivno utjecati na distorziju tržišta ili će i same postati predmetom spora.

Vjerojatno je i to da će neki organizatori natjecanja dokazivati kako su striktne zdravstvene mjere, koje su poduzele nacionalne vlade, dovele do indirektne eksproprijacije, te da temeljem toga imaju pravo na naknadu, pozivajući se na načelo sadržano u čl. 17. Povelje o temeljnim pravima $\mathrm{EU}^{133}$ u kojem se govori o pravu na vlasništvo. Naime, temeljem navedenog članka, ,vlasništvo nikome ne može biti oduzeto, osim u javnom interesu u slučajevima i pod uvjetima koje propisuje zakon, ako se pravodobno isplati pravična naknada za gubitak vlasništva“.

Međutim, ugovorni sporovi rješavat će se u postupcima pred sudom. Prvo sporno pitanje bit će pitanje kad je uopće nastupila viša sila, od kada do kada je trajala, kakve su njezine posljedice u svakom konkretnom slučaju. Kao što je očito iz svega navedenog, pravna pozicija svakog od navedenih aktera bitno je drugačija. Svaki ugovor je priča za sebe, počevši od toga o kakvom je ugovoru riječ, sadrži li uopće klauzulu o višoj sili, koje je pravo mjerodavno, kakva je praksa odnosnog pravosuđa u odnosu na višu silu, postoje li drugi mehanizmi kao odgovor na promijenjene okolnosti itd. K tome, mnogo će toga ovisiti i o okolnostima svakog pojedinog slučaja. Primjerice, je li određeni sportski događaj samo odgođen, ili je u cijelosti otkazan? Je li riječ o izoliranom događaju ili o seriji međusobno povezanih događanja (ugovoru s trajnim ili sukcesivnim prestacijama) itd.

Imajući u vidu intenzitet i raspon epidemije, neke su države nastojale ublažiti pravne posljedice gospodarskog poremećaja izdavanjem certifikata čime bi se oslobodilo stranke odgovornosti zbog neispunjenja svojih ugovornih obveza uslijed iznimnih okolnosti izvan njihove kontrole. Tako je, primjerice, kinesko Vijeće za promoviranje međunarodne trgovine ${ }^{134}$ omogućilo izdavanje certifikata o višoj sili svima koji posluju s inozemstvom i čije je poslovanje pogođeno COVID-om 19. Do 11. ožujka 2020. izdano je ukupno 5637 takvih certifikata. ${ }^{135}$ Izvjesno je da će navedeni certifikati znatno olakšati sudovanje u sporovima bez međunarodnog obilježja. Međutim, takvi certifikati ne obvezuju Arbitražni sud za sport ni pravosuđa drugih država, niti mogu anulirati relevantne ugovorne odredbe ili odredbe mjerodavnog prava, što znači da su praktično bez značaja u prekograničnim sporovima. ${ }^{136}$

Sve navedeno upućuje samo na jedan mogući odgovor, a taj je da u odnosu na pravne posljedice COVID-a 19 ne postoji panaceja. Odgovor je moguće dati samo za konkretan slučaj, imajući u vidu sve okolnosti tog konkretnog slučaja.

133 S1. 1. EU C 2020/389, od 7. VI. 2016.

134 The China Council for the Promotion of International Trade (CCPIT), akreditiran od strane kineskog Ministartsva gospodarstva.

135 Vidi: https://www.reuters.com/article/health-coronavirus-china-forcemajeure/china-force-majeurecertificate-issuance-pass-5600-amid-virus-outbreak-trade-body-idUSL4N2B43CK, preuzeto. 11. III. 2020.

136 Isto vrijedi i u slučaju Indije, koja je 19. veljače 2020. godine objavila službeno tumačenje da se poremećaj lanaca opskrbe uzrokovan širenjem COVID-a 19 u Kini ili bilo kojoj drugoj državi treba smatrati prirodnom katastrofom, a time i ,višom silom“, gdje god je to prikladno, poštujući propisani postupak. https:// doe.gov.in/sites/default/files/Force\%20Majeure\%20Clause\%20-FMC.pdf, preuzeto 4. VI. 2020. 


\section{LITERATURA}

1. Ačanski, T.: „Teorija shvaćanja o pojmu više sile“, Zbornik radova Pravnog fakulteta u Novom Sadu, br. XI., 1977., str. 144-155.

2. Ambrose, C.: „Force Majeure in International Contracts - The English Law Perspective“, Bus. L. Int'l 2003., str. 237-238.

3. Augenblick, M., Rousseau, A. B.: „Force Majeure in Tumultuous Times: Impracticability as the New Impossibility“, 13 J. World Investment \& Trade, 2012.

4. Beale, H. (ur.): Chitty on Contracts, Sweet \& Maxwell, 2019.

5. Bell, J. et al.: Principles of French Law, Oxford University Press, 2008.

6. Biondi, A.; Eeckhout, P.; Flynn, J.: The Law of State Aid in the European Union, Oxford Scholarship Online, March 2020.

7. Brunner, C.: „Force Majeure and Hardship under General Contract Principles: Exemption for Non-Performance in International Arbitration", Kluwer International, 2009.

8. Buxbaum, H. L.: Mandatory Rules in Civil Litigation: Status of the Doctrine PostGlobalization, Articles by Maurer Faculty, Paper 292, http://www.repository.law. indiana.edu/facpub/292, preuzeto 23. V. 2016.

9. Cesarec Nöthig, S., Štaba, R.: Epidemija virusom SARS-CoV-2 (COVID-19; „KORONAVIRUS“) - viša sila kao razlog isključenja ili ograničenja odgovornosti, https://www.psod.hr/objave/epidemija-virusom-covid-19-koronavirus---visa-sila, preuzeto 16. III. 2020.

10. Chua, W., Ahuja, S.: COVID-19 (Coronavirus), Force Majeure and Construction (Part II) - Outbreak of Disputes? Or Abatement in due course?, http://dentons.rodyk. com/en/insights/alerts/2020/february/20/covid19-force-majeure-annd-construction-part-ii , preuzeto 20. II. 2020.

11. Draeta, U.: Force Majeure Clauses in International Trade Practice, 5 Int'l Bus. L. J. 547, 1996.

12. Garro, A. M.: Comparison between provisions of the CISG regarding exemption of liability for damages (Art. 79.) and the counterpart provisions of the UNIDROIT Principles (Art. 7.1.7.), Pace Law School Institute of International Commercial Law, 2005.

13. Heiss, H.: „Party autonomy“, u: Ferrari, F., Leible, S. (ur.), Rome I Regulation, The Law Applicable to Contractual Obligations, Munich: Sellier, European law publishers $\mathrm{GmbH}$, str. 1-16.

14. Kadner Graziano, T.: Comparative Contract Law: Cases, Materials and Exercises, Edward Elgar Publishing, 2019.

15. Katsivela, M.: „Contracts: Force Majeure Concept or Force Majeure Clauses“, 12(1) Uniform Law Review, 2007., str. 101-120.

16. Kokorin, I., van der Weide, J.: „Force Majeure and Unforseen Change of Circumstances. The Case of Embargoes and Currency Fluctuations (Russian, German and French approaches)“, Russian Law Journal, Vol. III, Issue 3, 2015. 
17. Kunda, I.: „Defining Internationally Mandatory Rules in European Private International Law of Contracts“, Zeitschrift für Gemeinschaftsprivatrecht (GPR), Vol. 4, No. 5, 2007., str. 210-220.

18. Laithier, Y.-M.: „Comparative Reflections on the French Law of Remedies for Breach of Contract“", u: Cohen, N., McKendrick, E. (ur.): Comparative Remedies for Breach of Contract, Hart Publishing, 2005.

19. Liu, C.: Changed Contract Circumstances (2nd edition: Case annotated update), travanj 2005., http://www.cisg.law.pace.edu/cisg/biblio/liu5.html, preuzeto 6. IV. 2020.

20. Liu, C.: Remedies for Non-performace: Perspectives from CISG, UNIDROIT Principles and PECL, http://www.cisg.law.pace.edu/cisg/biblio/chengwei-79.html, preuzeto 6. IV. 2020.

21. Malaurie, Ph.; Aynès, L.; Stoffel-Munck, Ph.: Les obligations, Defrénois, Paris, 2011.

22. Matijević, B.: Viša sila u obveznom pravu, IUS-INFO, 22. VIII. 2017.

23. Mazzacano, P.: „The Treatment of CISG Art. 79 in German Courts: Halting the Homeward Trend“, Nordic Journal of Commercial Law, 2, 2012., http://njcl. fi/2_2012/mazzacano_peter.pdf, preuzeto 1. IV. 2020.

24. Medić, I.: „Applicable Law for Contracts in Sporting Context“, Journal of South East European University (SEEU Review), Vol. 12, Issue 1.

25. Medić, I.: „Lex Contractus and Overriding Mandatory Rules. What Can We Learn from the CJEU Case Law?", Book of Proceedings, 16th International Scientific Conference on Economic and Social Development „The Legal Challenges of Modern World“, No. 16, Split, 2016., str. 43-52.

26. Medić, I.: „Međunarodno privatno pravo u sportu (kolizijske norme)“, u: Kačer, H. et. al.: Sportsko pravo, Split: Pravni fakultet, 2018., str. 447-473.

27. Medić, I.: „Significance of Mandatory Rules in International Commercial Arbitration“, Book of Proceedings, 19th International Scientific Conference on Economic and Social Development, No. 19, Melbourne, 2019., str. 38.-46.

28. Melis, W.: Force Majeure and Hardship Clauses in International Commercial Contracts in View of the Practice of the ICC Court of Arbitration, 1 J. Int'1 Arb. 231, 1984., str. 213-221.

29. Nicholas, B.: „Force Majeure in French Law“, u: McKendrick (ur.), Force Majeure and Frustration of Contract, Informa Law from Routledge, 2013.

30. Nicholas, B.: „Impracticability and Impossibility in the U.N. Convention on Contracts for the International Sale of Goods“, u: Galston \& Smit (ur.), International Sales: The United Nations Convention on Contracts for the International Sale of Goods, 1984., str. 5-1 do 5-24.

31. Pauknerová, M.: „Mandatory rules and public policy in international contract law“, ERA Forum, 2010. (Vol. 11, No. 1), str. 29.-43.

32. Perillo, J.: „Force Majeure and Hardship Under the UNIDROIT Principles of International Commercial Contracts“, 5 Tul. J. Int'L. \& Comp., 1997. 
Izv. prof. dr. sc. Ines Medić: Učinak COVID-a 19 na prekogranične ugovore vezane uz organizaciju... Zbornik radova Pravnog fakulteta u Splitu, god. 58, 1/2021, str. 121-150

33. Petrić, S.: „Izmjena ili raskid ugovora zbog promijenjenih okolnosti prema novom Zakonu o obveznim odnosima“, Zbornik Pravnog fakulteta Sveučilišta u Rijeci (1991.), v. 28 br. 1, 2007.

34. Polkinghorne, M., Rosenberg, C.: „Expecting the Unexpected: the Force Majeure Clause“, Buss. Law Int'l, Vol. 16, No. 1, 2015.

35. Puelinckx, A. H.: „Frustration, Hardship, Force majeure, imprévision, Wegfall der Geschäftsgrundlage, Unmöglichkeit, Changed Circumstances“", J. Int'l Arb. 47, 1986.

36. Rauh, T.: „Legal Consequences of Force Majeure under German, Swiss, English and United States Law“, 25 Dev. J. Int'l Law \& Pol'y 151, 1996.

37. Ridder, P., Weller, M.-P.: „Unforseen Circumstances, Hardship, Impossibility and Force Majeure under German Contract Law“, 22 European Review of Private Law, 2014.

38. Riedel, P.; Wilson, T.; Cranley, S.: EU State Aid and COVID-19, http:// competitionlawblog.kluwercompetitionlaw.com/2020/03/24/eu-state-aid-andcovid-19/, preuzeto 24. III. 2020.

39. Rimke, J.: Force majeure and hardship: Application in international trade practice with specific regard to the CISG and UNIDROIT Principles of International Commercial Contracts, https://www.cisg.law.peace.edu/cisg/biblio/rimke.html, preuzeto 6. III. 2020.

40. Sánchez Lorenzo, S.: „Choice of law and overriding mandatory rules in international contracts after Rome I“, Yearbook of Private International Law, Vol. 12, 2010., str. 61-79.

41. Schlechtriem, P.: Schuldrecht: Allgemeiner Teil, Mohr Siebeck, 2003.

42. Schmitthoff, C.M., Adams, J.: Schmithoff's Export trade: the law and practice of international trade, UCLA, 1986.

43. Schwartze, A.: „New Trends in Partie's Options to Select the Applicable Law? The Hague Principles on Choice of Law in International Cotracts in a Comparative Perspective“, University of St. Thomas Law Journal, Vol. 12, No 1, 2015., str. 87-99.

44. Schwenzer, I.: „Force Majeure and Hardship in International Sales Contracts“, 39 VUWLR 2008.

45. Smitz, T.: Force Majeure: What to do if?, https://solutions.belfor.com/en-eu/forcemajeure-what-do-if, preuzeto 15. III. 2020.

46. Symeonides, S. C.: „Party Autonomy in Rome I and II From a Comparative Perspective". U: Boele-Woelki, K. et al. (ur.), Convergence and Divergence in Private International Law - Liber Amicorum Kurt Siehr, Zürich: Eleven International Publishing, str. 513-550.

47. Terré, F.; Lequette, Y.; Simler, Ph.: Les obligations, Dalloz-Sirey, 2009.

48. Thibierge, L.: „Force Majeure and Its Effects“, Int'l Bus. L. J. 2017., str. 603-617.

49. Vedriš, M., Klarić, P.: Građansko pravo, Narodne novine, 1998.

50. Vuković, M.: Opći građanski zakonik, Školska knjiga, Zagreb, 1955.

51. Wright, W. C.: „Force Majeure Delays“, 26 Constr. Law, 2006.

52. Wojewoda, M.: „Mandatory Rules in Private International Law“, Maastricht J. Eur. \& Comp. L., Vol. 7, No. 2, 2000., str. 183.-213. 


\section{PRAVNI PROPISI}

1. Konvencija UN-a o međunarodnoj prodaji robe (1980.). Prijevod teksta na hrvatski jezik dostupan je na: http://www.cisg.law.pace.edu/cisg/text/CISGCRO.html

2. Francuski građanski zakonik (ugovori). Prijevod na engleski jezik dostupan je na www.legifrance.gouv.fr $>$ version $>$ file $>$ Code_22

3. Francuski građanski zakonik (ugovori), noveliran 2016. Prijevod na engleski jezik dostupan je na https://www.trans-lex.org/601101/_french-civil-code-2016/

4. Njemački Građanski zakonik. Prijevod na engleski jezik dostupan je na https://www. gesetze-im-internet.de/bgb/BJNR001950896.html

5. Povelja o temeljnim pravima EU, Sl. 1. EU C 2020/389, od 7. VI. 2016.

6. Švicarski Građanski zakonik. Prijevod na engleski jezik dostupan je na https://www. wipo.int/edocs/lexdocs/laws/en/ch/ch310en.pdf

7. Uredba (EZ) br. 593/2008 Europskog parlamenta i Vijeća od 17. lipnja 2008. o pravu koje se primjenjuje na ugovorne obveze (Uredba Rim I), Sl. l. L 177, od 4. VII. 2008.

8. Zakon o međunarodnom privatnom pravu RH, NN br. 101/17

9. Zakon o obveznim odnosima RH, NN br. 35/05, 41/08, 125/11, 78/15, 29/18

10. Code of Sports-Related Arbitration, na snazi od 1. siječnja 2019. godine. https://www. tas-cas.org/fileadmin/user_upload/Code_2019_en_.pdf, preuzeto 12. XI. 2019.

\section{SUDSKE ODLUKE}

1. Odluka u predmetu BGE 101 II 17, švicarski Vrhovni sud

2. Odluka u predmetu BGE 122 III 97, švicarski Vrhovni sud

3. Odluka u predmetu BGE 68 II 173, švicarski Vrhovni sud

4. Odluka u predmetu BGE 93 II 185, švicarski Vrhovni sud

5. Odluka u predmetu BGE 07 II 343, švicarski Vrhovni sud

6. Odluka u predmetu BGE 100 II 345, švicarski Vrhovni sud

7. Odluka u predmetu BGE 111 II 352, švicarski Vrhovni sud

8. Odluka u predmetu BGE 97 II 398, švicarski Vrhovni sud

9. Odluka u predmetu 2C_579/2011, švicarski Savezni sud

10. Odluka u predmetu ATF 100 II 345, švicarski Savezni sud

11. Odluka u predmetu ATF 111 II 429, švicarski Savezni sud

12. CAS 2002/A/388 Ülker Sport/Euroleague, 10. IX. 2002.

13. CAS 2005/A/957 Club Atlético Mineiro v. FIFA, 23. III. 2006.

14. CAS 2006/A/1110 PAOK FC v. UEFA, 25. VIII. 2006. (operativni dio od 13. VII. 2006.)

15. CAS/2007/A/1380 MKE Ankarangücü Spor Külübu v. S., 11. VI. 2008.

16. CAS 2013/A/3471 Dnipro v. Football Federation of Ukraine (FFU), 16. VI. 2014. (operativni dio od 24. III. 2014.)

17. CAS 2014/A/3463 \& 3464 Alexandria Union Club v. Sánchez \& Cazorla, 26. VIII. 2014. 
18. CAS 2014/A/3533 Football Club Metalurg v. UEFA 9. IX. 2014.

19. CAS 2015/A/3909 Club Atlético Mineiro v. FC Dynamo Kyiv, 2. X. 2015.

20. CAS 2016/A/4402 Pathrakikos FC v. FIFA, 20. IX. 2016.

21. CAS 2016/A/4852 Zamalek Sporting Club v. Karim Alhassan, 13. X. 2017.

22. CAS 2018/A/5537 Zamalek Sporting Club v. FIFA, 31. X. 2018.

23. CAS 2018/A/5779 Zamalek Sporting Club v. FIFA, 31. X. 2018.

24. Paradine v Jane 82 KB 1647, Eng. Rep. 897

25. RDC Concrete Pte Ltd v Sato Kogyo (s) Pte Ltd [2007] 4 SLR(R) 413

26. Coastal (Bermuda) Petroleum Ltd v VTT Vulcan Petroleum SA (the Marine Star (No 2)) [1996] 2 Loyd's rep. 383

27. British Electrical and Associated Industries (Cardiff) Ltd v Patley Pressings Ltd [1953] 1 W.L.R. 280

28. Holcim (Singapore) Pte Ltd v Precise Development Pte Ltd [2011] 2 SLR 106

29. Lebeaupin v Richard Crispin \& Co [1920] 2 KB 714

30. Seadrill Ghana Operations Ltd v Tullow Ghana Ltd [2018] EWHC 1640

31. Thames Valley Power Ltd. V Total Gas \& Power Ltd [2005] EWHC 2208

32. Great Elephant Corporation v Trafigura Beheer BV (The Crudesky) [2013] 2 All E.R. (Comm) 992

33. Channel Island Ferries Ltd v Sealink UK Ltd [1988] 1 Lloyd's Rep 323

34. Classic Maritime v Limbungan Makmur [2018] EWHC 2389 (66)

35. VSRH, Rev 131/1991-2, od 23. XII. 1992.

36. VSRH Rev 930/2009-2., od 31. I. 2012.

37. VSRH Gzz 44/1991-2, od 17. XII. 1991.

38. VTSRH, Pž 160/93, od . 15. VI. 1993.

39. VSRH Rev 2521/1995-2, od 4. II. 1996.

40. VSRH Gzz 44/1991/2, od 17. XII. 1991.

\section{INTERNETSKI IZVORI}

1. Marjanović, V.: Ni koronavirus ih ne može iznenaditi, osiguranje im plaća štetu 114 milijuna funti, https://novac.jutarnji.hr/makro-mikro/ni-koronavirus-ih-ne-mozeiznenaditi-osiguranje-im-placa-stetu-114-milijuna-funti/10203793/, preuzeto 14. IV. 2020.

2. https://www.reuters.com/article/health-coronavirus-china-forcemajeure/chinaforce-majeure-certificate-issuance-pass-5600-amid-virus-outbreak-trade-bodyidUSL4N2B43CK, preuzeto 11. III. 2020.

3. https://ec.europa.eu/competition/state_aid/what_is_new/covid_19.html, preuzeto 3. IV. 2020. https://www.bbc.com/sport/cycling/52050109, preuzeto 5. IV. 2020.

4. https://www.sportspromedia.com/news/bein-sports-lfp-ligue-1-tv-rights-instalmentssuspended-coronavirus, preuzeto 5. IV. 2020.

5. https://www.sportsbusinessdaily.com/Journal/Issues/2020/04/06/Sports-and-Society/ NBA-pay.aspx, preuzeto 13. IV. 2020. 
6. ESPN: Coronavirus cancellations and reactions in sports, https://www.espn.com/ espn/story/_/id/28871525/coronavirus-cancellations-reactions-sports, preuzeto 24. IV. 2020.

7. https://img.fifa.com/image/upload/zyqtt4bxgupp6pshcrtg.pdf, preuzeto 25. IV. 2020.

\section{EFFECTS OF COVID-19 ON CROSS-BORDER CONTRACTS RELATED TO THE ORGANIZATION OF SPORTING COMPETITIONS}

In circumstances where cross-border mobility of things and people was taken for granted, the pandemic scale of the SARS-CoV-2 virus epidemic (colloquially called COVID-19 or coronavirus) resulted in dramatic and, until yesterday, unimaginable consequences. Namely, in the regular course of things we mainly focused on its positive effects, but the current epidemic has completely exposed its ,other face“. COVID-19 proved to be the best ,stres test“ for cross-border mobility of persons and cross-border economic relations and pointed out all the weaknesses of excessive reliance on globalization per se. The effects of COVID-19 on every aspect of life and on humaity as a whole can be called colossal. Numerous sectors, including sports, were „killed“ by the epidemic. Most sports competitions, especially regional and global, have been cancelled or postponed (in)defiitelly. Federations and organizers of sports competitions have found themselves in major trouble due to the inability to meet their contractual obligations to sponsors, the media and other contracting parties. The intention of the autor of this paper is to try to answer a question that bothers many these days, and that is the possibility of excluding or limiting contractual liability by invoking force majeure.

Key words: cross-border mobility, organization of sports competitions, cross-border contracts, force majeure, European Union, global perspective 